\title{
JAGIELLOŃSKA FUNDACJA WYDZIALU TEOLOGICZNEGO W KRAKOWIE
}

Mówiąc o epoce, która zaistniała między starożytnością a nowożytnością, trzeba sobie uświadomić fakt, że wieki średnie były różnie oceniane, najczęściej pejoratywnie. Co więcej, z zamysłem urabiano o nich fałszywy obraz, określając je mianem saecula obscura - wiekami ciemnymi i potępiając przy tym w czambuł to, co w nich się zrodziło. Dopiero źródłowe badania obecnego stulecia przyczyniają się coraz bardziej do ukazania prawdziwego oblicza wieków średnich i do wykazania, że nowożytne życie umysłowe jest we wielu wypadkach właściwie rozwinięciem czy nawet kontynuacją myśli średniowiecznej $^{1}$. Dotyczy to też między innymi organizacji wyższych uczelni.

Szkoły wczesnego średniowiecza, które powstały początkowo przy głównych klasztorach i były dopiero od IX wieku z nakazu papieża Eugeniusza II zakładane w stolicach biskupich, opierały się na odziedziczonym po starożytności systemie nauczania; sprowadzał się on do nauczania umiejętności wyzwolonych (artes liberales), obejmujących jedynie elementy greckiej i rzymskiej wiedzy. Dla podstawowego wykształcenia kleru, jeżeli do tego doszła jeszcze oparta na Biblii wiedza teologiczna, było to w tym czasie wystarczające ${ }^{2}$. Stopniowe poznawanie w XII i XIII wieku dalszej spuścizny naukowej antyku, świata bizantyńskiego i arabskiego poszerzyło nie tylko horyzonty myślowe średniowiecznych uczonych, lecz także dało im nowe inspiracje i większe impulsy we wielu dziedzinach do właściwej twórczości naukowej. To zaś nie mieściło się już w kanonie siedmiu artes liberales. Tego programu nauczania bynaj-

* Nota redakcyjna: Dnia 11 stycznia 1989 roku Papieska Akademia Teologiczna w Krakowie uczciła zbliżający się jubileusz sześćsetlecia Wydziału Teologicznego Uniwersytetu Jagiellońskiego zorganizowaniem sesji naukowej - pierwszej z dziewięciu zamierzonych w najbliższych latach (do roku 1997). Sesja odbyła się w katedrze wawelskiej. Publikowany poniżej tekst jest poszerzoną wersją referatu, wygłoszonego tam wówczas przez Autora.

BJ W - rękopis Biblioteki Jagiellońskiej w Krakowie

BUW - rękopis Biblioteki Uniwersytetu Wrocławskiego

KodUJ - Codex diplomaticus universitatis studii generalis Cracoviensis, t. 1, Cracoviae 1870.

PSB - Polski stownik biograficzny. s. 28.

${ }^{1}$ S. S wi ża ws ki, Dzieje filozofii europejskiej w XV wieku. T. 1: Poznanie, Warszawa 1974,

2 J. B a szki e wi cz, Mtodość uniwersytetu, Warszawa 1963, s. 11 - 12. 
mniej nie zlikwidowano. Obowiązywał on nadal w szkołach istniejących przy klasztorach, katedrach i kolegiatach. Obok nich zaczęto w XII wieku tworzyć nowy typ uczelni, które stały się ośrodkami otwartego nauczania bardziej wyspecjalizowanych dziedzin wiedzy. W przeciwieństwie do już istniejących szkół partykularnych nowa instytucja naukowa otrzymała nazwę studium generalne. Jej wykładowcy i studenci tworzyli na wzór średniowiecznych cechów autonomiczną korporację, zwaną universitas magistrorum et scholarium. Dopiero w późniejszych czasach nazwę tej korporacji rozciągnięto na samą instytucję. Społeczność nauczających i studiujących zdobywszy swoje dodatkowe prawa i przywileje stała się w XIII wieku, obok władzy duchowej (sacerdotium) i doczesnej siły monarchii (regnum), trzecią władzą rządzącą światem (studium). Urabiano pogląd, że te trzy władze, tj. sacerdotium, regnum i studium, lub inaczej mówiąc: wiara (fides), siła zbrojna (militia) i mądrość (sapientia), stanowią podstawę dobrego ustroju państwa. Święty Tomasz z Akwinu i jego uczeń Idzi R ymianin uważali nawet, że tyranem jest władca, który nie dba o oświatę poddanych i o rozwój wiedzy w swoim kraju ${ }^{3}$.

W obrębie społeczności nauczających i uczących się duże znaczenie miał podział na tzw. nacje. Obejmował on albo profesorów i scholarów, albo tylko tych ostatnich. Podstawę tego podziału stanowiło raczej kryterium geograficzne niż narodowościowe. Wyodrębniano zazwyczaj cztery nacje.

W miarę podnoszenia się poziomu nauczania, a zwłaszcza poszerzania się programu nauczanych przedmiotów, zaczęto w studium generalnym tworzyć określone specjalizacje. Dotyczyło to głównie filozofii, medycyny, prawa i teologii. Przy wyodrębnianiu tych dziedzin wiedzy i przy opracowywaniu dla każdej z nich oddzielnego programu nauczania zaszła potrzeba nadania im trwałych struktur. Nazwano je fakultetami. W ten sposób słowo facultas otrzymało w roku 1355 znaczenie dzisiejszego wydziału w wyższych uczelniach ${ }^{4}$. W połowie XIII wieku ukształtowało się przekonanie, że studium generale w pełnym tego słowa znaczeniu miało obejmować całokształt wiedzy średniowiecznej, czyli posiadać cztery fakultety. Tak zorganizowana instytucja naukowa nie posiadała podobnych wzorów w organizacji szkolnictwa ani starożytnego, ani bizantyńskiego, ani arabskiego. Powstała ona w wyniku naukowych aspiracji społeczeństwa średniowiecznego w okresie najwspanialszego rozkwitu scholastyki.

W XIII wieku papieże zaczęli oględnie interesować się żywiołowym ruchem naukowym, w wyniku którego powstały studia generalne. Nadając im pewne przywileje, przyczyniali się z jednej strony do stabilizacji autonomicznej korporacji nauczycieli i studentów, $\mathrm{z}$ drugiej zaś strony rozciągali oni zrazu

\footnotetext{
${ }^{3}$ Tamże, s. 8.

${ }^{4} \mathrm{~F}$. Schu tze, P. Ss y m a n k, Das deutsche Studententum von den ältesten Zeiten bis zur Gegenwart - 1931, München 1932, s. 9.
} 
niepostrzeżenie, a z biegiem czasu coraz jawniej swoją nad nią kontrolę. Regulowali oni formy ustrojowe i wewnętrzną organizację zwłaszcza tych uczelni, w których uczono teologii. Dzięki takiemu nadzorowi papieskiemu umacniał się autorytet uczelni. Studium generale w Paryżu stało się w ten sposób już w trzecim ćwierćwieczu XIII wieku największym ośrodkiem studiów teologicznych dla całego Kościoła zachodniego. W XIV wieku, gdy studia generalne pod względem organizacyjnym ustabilizowały się jako wyspecjalizowane instytucje naukowe, papieskie zatwierdzenie fundacji stało się nieodzownym warunkiem ich zaistnienia. Przy tym $\mathrm{z}$ reguły nie udzielano zgody na erekcję wydziału teologii. W tym względzie dla kontynentu europejskiego monopol miał posiadać tylko Uniwersytet Paryski. Barierę tę przełamał Karol IV Luksemburczyk, który nie jako król Czech, ale jako przyszły cesarz rzymski narodu niemieckiego dnia 26 stycznia 1347 roku od swojego byłego wychowawcy, papieża Klemensa VI uzyskał zezwolenie na założenie w Pradze czterowydziałowej wyższej uczelni na wzór paryski. Tenże papież zgodził się w 1360 roku na studia teologii w starym i słynącym $\mathrm{z}$ wysokiego poziomu nauczania prawa studium generalnym w Bolonii. Jego następca Urban V pozwolił w 1363 roku na erekcję wydziału teologii w Padwie. Te decyzje papieskie ośmieliły i zachęciły królów Kazimierza Wielkiego i Ludwika I Andegaweńskiego oraz arcyksięcia austriackiego Rudolfa IV Habsburga do wystąpienia w latach sześćdziesiątych XIV wieku do Urbana V z prośbą o zezwolenie na fundację w stolicach ich krajów studium generalnego typu parysko-praskiego. Otrzymali jednak papieskie zatwierdzenie na uruchomienie tylko trzech wydziałów, tj. prawa, medycyny i sztuk wyzwolonych wraz z filozofią ${ }^{5}$. Odmowa na założenie fakultetu teologii sprawiła, że w programie nauczania uczelni Kazimierzowskiej na czołowe miejsce wysunęła się nauka prawa rzymskiego i kanonicznego. Jednak myśli o czterowydziałowym studium ostatni monarcha $\mathrm{z}$ dynastii piastowskiej bynajmniej nie porzucił. W wydanym dnia 12 maja 1364 roku dyplomie założenia studium generalnego w Krakowie stwierdził: „Postanowiliśmy w mieście naszym Krakowie wyznaczyć, obrać, ustanowić i urządzić miejsce, na którym by szkoła generalna w każdej dozwolonej dziedzinie kwitnęła, a dla przyszłości na wieczne czasy tym pismem jej istnienie zapewnić chcemy"6.

5 „Dicti Regis in hac parte supplicationibus inclinati, de fratrorum nostrorum consilio, auctoritate apostolica statuimus et etiam ordinamus: ut in dicta civitate Cracoviensi de caetero sit Studium generale, illudque perpetuis temporibus inibi vigeat, tam in Iuris Canonici et civilis, quam alia qualibet licita, praeterquam in Theologia, facultate" (KodUJ 1 s. 7; bulla Urbana V z 1 września 1364, zezwalająca na otwarcie w Krakowie studium generalnego z trzema wydziałami, z wyjątkiem teologicznego). Zob.: A. V e tu l a n i, Poczatki najstarszych wszechnic środkowoeuropejskich, Wroclaw 1970, s. 66 - 67; A. P a r t y k a, Papieskie zatwierdzenia fundacji uniwersytetów środkowoeuropejskich w latach 1347-1386, „Analecta Cracoviensia” 9:1977 s. 10.

${ }^{6} \mathrm{~W}$ polskim tłumaczeniu wprowadzono nieznaczne zmiany. Por.: S. Krz yż a now ski, Poselstwo Kazimierza Wielkiego do Awinionu i pierwsze przywileje, „Rocznik Krakowski” 4:1900 s. 62 -63; A. Vet u l a ni, Poczqtki uniwersyteckiej nauki prawa w Polsce, „Ruch Prawniczy, Ekonomiczny i Socjologiczny" 3: 1968 s. 257. 
Osłabienie władzy papieskiej przez wielką schizmę i chęć utrzymania dobrych kontaktów $\mathrm{z}$ władcami świeckimi sprawiły, że począwszy od lat osiemdziesiątych XIV stulecia papieże chętniej i prędzej wyrażali zgodę na tworzenie czterowydziałowych studiów generalnych. Dotyczyło to tak już istniejących, jak i nowo zakładanych uczelni. W latach od 1385 do 1391 Stolica Apostolska wydała aż dziewięć zatwierdzeń fundacji wydziału teologii, tj. w Wiedniu (1384), w Heidelbergu (1385), w Chełmie (1386), w Lukce (1387), w Kolonii (1388), w Erfurcie (1389), w Pawii (1389), w Budzie (1390) i w Ferrarze $(1391)^{7}$.

Wydane w rekordowo krótkim czasie przez Urbana VI (9 lutego 1386) papieskie zatwierdzenie supliki krzyżackiej na fundację w Chełmie nad Wisłą studium generalnego $\mathrm{z}$ wydziałem teologii stanowiło niemałe zaskoczenie dla polskiej władzy, tak świeckiej, jak i kościelnej. Zakon krzyżacki, chociaż zgodził się w roku 1385 na zawarcie z Polską rozejmu, nie zrezygnował bynajmniej z myśli zawładnięcia ziem litewskich. Tym razem miało to nastąpić nie przy użyciu miecza, ale przez ekspansję kulturalną i pod osłoną misji. Zanim jednak zdołano przywieźć do Malborga papieski dokument, zezwalający na założenie w Chełmie czterowydziałowego studium, te zamiary krzyżackie udaremniła lśniąca od 16 października 1384 roku blaskiem korony Polski dwunastoletnia Jadwiga, gdy 18 lutego 1386 roku w katedrze na Wawelu do ołtarza poprowadziła dojrzałego oblubieńca Władysława Jagiełłę, wielkiego księcia Litwy. Dzięki temu małżeństwu Litwini zostali formalnie wciągnięci w orbitę wpływów zachodniej kultury łacińskiej i Kościoła rzymskiego. Chociaż całe dzieło misyjne czekało na swoją realizację, zakon krzyżacki zrozumiał, że nie będzie mu dane przeprowadzić uchrześcijanienia pogańskiej Litwy. W tej sytuacji zaprzestał on dalszego forsowania, zmierzającego do uruchomienia własnej wyższej uczelni w Chełmie.

Niemniej ugodzony tym aktem krzyżackim prestiż Polski w ogólności, a jej stołecznego miasta Krakowa w szczególności, nie został bynajmniej wymazany ze świadomości ani panów polskich, stojących przy sterze wielkiej polityki potężnego państwa polsko-litewskiego, ani polskiego episkopatu, zatroskanego szerzeniem wiary, ani intelektualistów zajmujących się oświatą w kraju. W tych warunkach sprawa odnowienia podupadłego studium generalnego fundacji ostatniego króla-Piasta i wielka idea założenia jeszcze wydziału teologii stały się zadaniem nie cierpiącym dalszej zwłoki. Przy tym łatwiejsze było uruchomienie trzywydziałowego studium fundacji Kazimierzowskiej, gdyż ono nie wymagało nowego zatwierdzenia papieskiego. Dyplomatycznych zabiegów wymagało natomiast uzyskanie papieskiej zgody na dodatkowe założenie fakultetu teologii. W obydwu przypadkach pojawiły się jednak wielkie trudno-

${ }^{7} \mathrm{H}$. De nifl e, Die Universitäten des Mittelalters bis 1400 , Bd. 1, Berlin 1885, s. 322, 380, 387, $428,572,648$. 
ści natury zewnętrznej i wewnętrznej. Przypomniał je kilkanaście lat później krakowski profesor teologii Franciszek z Brzegu. Powiedział on wprost, że realizacja tego wspaniałego przedsięwzięcia odbyła się ,non sine magnis fastidiis" 8 , a więc w okolicznościach budzących pewien niesmak czy nawet wstręt.

Jeżeli wierzyć wspomnianemu teologowi i wicekanclerzowi Uniwersytetu Krakowskiego, Franciszkowi z Brzegu, to z prośbą o zezwolenie na fundację wydziału teologii w Krakowie wystąpiono jeszcze na pontyfikatu Urbana VI, a więc przed 15 października 1389 roku ${ }^{9}$. W tym czasie biskupem diecezji krakowskiej był Jan zwany Radlicą (od 1382 do 12 I 1392), który nominację na biskupa otrzymał właśnie od tego papieża. Być może, że to Jan Radlica, który asystował przy ślubie Jadwigi i Władysława Jagiełły, podsunął im myśl odnowienia podupadłego Uniwersytetu Krakowskiego i erygowania w nim jeszcze wydziału teologii. Trudno bowiem przypuszczać, żeby z taką inicjatywą wystąpił nowy król, który w obliczu orężnego zagrożenia ze strony Krzyżaków na pierwszy plan wysunął umocnienie sojuszu polsko-litewskiego i scalenie bądź co bądź dwóch odrębnych organizmów państwowych w jedną potężną monarchię. W tym przekonaniu utwierdzali go jego doradcy, reprezentujący interesy. nie tylko możnych rodów polskich, lecz także wpływowych rzesz rycerstwa, nie zawsze przychylnie nastawionego do poczynań duchowieństwa.

Jadwigę, jako córkę dwóch starych dynastii królewskich, andegaweńskiej i piastowskiej, od dzieciństwa wychowywano na dziedziczkę jednej z koron królestw europejskich. Dzięki niezwykle starannemu wykształceniu do niepospolitej urody doszła jeszcze niebywała kultura umysłu i szlachetność serca. Przyjeżdżając do Polski, znała ona nie tylko język swego dzieciństwa, język węgierski, ale i języki swego wychowania; niemiecki i łacinę. W kraju, do którego przybyła jako wnuczka Elżbiety Łokietkówny i siostrzenica Kazimierza Wielkiego, nauczyła się jeszcze języka polskiego. Mimo tych zalet Jadwigi nie sposób jest jednak przychylić się do poglądu, ażeby sama inicjatywa odrestaurowania podupadłego Uniwersytetu Krakowskiego i idea ufundowania wydziału teologii wyszła od tej kilkunastoletniej królowej.

Na taką inicjatywę i bieg jej rozwoju w tym zwrotnym okresie dziejów Polski i Litwy mieli o wiele większy wpływ doradcy. Wśród nich znajdowali się nie tylko wytrawni politycy z dalekosiężnym programem politycznym, lecz także światli dygnitarze kościelni, uwzględniający potrzeby duchowe społeczeństwa polskiego i litewskiego. Bogacące się mieszczaństwo niektórych miast polskich, zwłaszcza Krakowa, chcąc się wybić w hierarchii społecznej, zaczęło zdradzać coraz większe aspiracje kulturalne. Do podniesienia poziomu moral-

\footnotetext{
${ }^{8}$ Por. M. Gę ba rowi cz, Psałterz floriański i jego geneza, Wrocław 1965, s. 45. Z. Budkowa inaczej odczytała to ostatnie słowo rękopisu Biblioteki Uniwersytetu Wrocławskiego I Q 381: „non sine magnis fatigiis” (Z. B u d k ow a, Kodeks Mikotaja Tempelfelda, „Sprawozdania z Czynności i Posiedzeń PAU" 53 : 1952 s. 468).

${ }^{9}$ Z. Budk ow a, Kodeks..., s. 468.
} 
nego i umysłowego duchowieństwa, a przede wszystkim przygotowanie go do zaistniałych zadań misyjnych na rozległych obszarach północno-wschodnich, nie wystarczało wzmocnienie jego dyscypliny, lecz trzeba było mu dać lepsze i rozleglejsze wykształcenie. Urzeczywistnienie tego rozległego programu działalności kulturalnej i tych ambitnych poczynań naukowych wymagało wielkiego mecenatu. Do tego celu najlepiej było zjednać sobie Jadwigę, przepojoną wielkimi ideałami i zasadami religijności. O ile Władysław Jagiełło reprezentował polityczną siłę i władzę, której źródłem była jego małżonka jako dziedziczka korony polskiej, o tyle młoda królowa stała się trwałym uosobieniem i oficjalną realizatorką zarówno różnorodnych przedsiewzięć kulturalnych (nawet o randze trwałych pomników kultury, jak Psatterz floriański ${ }^{10}$ ), jak i inicjatyw naukowych o wymiarze epokowym. Do tych ostatnich należało uruchomienie w stolicy Polski czterowydziałowego studium generalnego $\mathrm{z}$ wydziałem teologii na czele.

Pełna realizacja idei tego wielkiego przedsiewzięcia, mimo że została podjęta przez pełnoprawną dziedziczkę korony polskiej, wymagała jeszcze zjednania przedstawicieli szerszych warstw społecznych. Najszybszy i najżywszy oddźwięk znalazła ona w kołach przebywającej w Krakowie inteligencji. Widać to choćby w mowach magistra nauk wyzwolonych i filozoficznych Bartłomieja z Jasła, wygłaszanych przezeń w Krakowie począwszy od 1390 roku$^{11}$. Zwrócił on uwagę między innymi na to, że odnowienie podupadłego studium generalnego, w którym by uczono mądrości, mogłoby stać się wielkim darem i dobrodziejstwem w porządku tak doczesnym, jak i wiecznym ${ }^{12}$. Poważny wkład w dzieło odnowy wszechnicy krakowskiej w latach dziewięćdziesiątych XIV wieku wnieśli jeszcze dwaj doktorzy prawa. Jednym $\mathrm{z}$ nich był Mikołaj z Gorzkowa, który w roku 1392 administrował diecezją krakowską i któremu nadano nawet miano ojca Uniwersytetu Krakowskiego ${ }^{13}$. Drugim z nich był Stanisław ze Skarbimierza, pierwszy rektor odnowionej wyższej uczelni krako-

${ }^{10}$ M. Gębarowicz, jw., s. 218.

${ }_{11}$ M. Kowalczyk, Barttomiej z Jasta a próba odnowienia Uniwersytetu Krakowskiego, „Sprawozdania z Posiedzeń Komisji Oddziału PAN w Krakowie” 1973 s. 130 - 134; taż, Odnowie"Sie Uniwersytetu Krakowskiego w świetle mów Barttomieja z Jasta, „Małopolskie Studia Historyczne" 6: 1964 s. $23-42$; Z. Kozl ow s k a-B u d k ow a, Odnowienie Jagiellońskie Uniwersytetu Krakowskiego (1390 - 1414), [w:] Dzieje Uniwersytetu Jagiellońskiego w latach 1364 - 1764, "t. 1, Kraków 1964, s. 37 n.; M. Ma r k ow s ki, Methodologische Grundlagen der offiziellen Universitätsbesclüsse und Erklärungen der Professoren an der Krakauer Universität im XV. Jahrhundert, „Studia Mediewistyczne" $17: 1977$ s. 7.

12 „Ex istis volens considerare perpendere posset, quantum donum seu beneficium sit Studium, in quo traditur et aquiratur sapiencia, non solum que ad salutem anime est necessaria, ut ex predictis et multis aliis stendi posset, sed eciam traditur in ipso sapiencia pro utilitate corporis temporali" (BJ 2192 f. 115 v); zob. M. Kow al s z y k, Odnowienie Uniwersytetu Krakowskiego.., s. 8.

13 „Est pater temporis maturitate, quia vir maturus et multarum experienciarum expertus [...] Est etiam pater communi nostra opinione, nam per magistros pater communiter Universitatis appelatur [...] Affectus ipsius domini rectoris ad Universitatem hanc exprimitur in eo, quod amat vos" (BJ 723 s. 287); zob. Z. Kozlow s k a-B u d k ow a, Odnowienie Jagiellońskie..., s. 57. 
wskiej i współredaktor statutów Wydziału Nauk Wyzwolonych i Filozoficznych $^{14}$.

Sprawa restauracji studium generalnego w Krakowie nie była też obca bogatemu mieszczaństwu krakowskiemu, które już przy Kazimierzowskiej fundacji w roku 1364 zobowiązało się do respektowania przywilejów i do wspierania autonomicznej korporacji magistrów i scholarów. Gdy w roku 1390 zaczęto poważniej zastanawiać się nad odnowieniem poupadłej instytucji naukowej, rada miasta Krakowa jeszcze w tym roku wysłała specjalnego gońca do Pragi $\mathrm{z}$ listem do syna jednego $\mathrm{z}$ rajców krakowskich, wybitnego profesora teologii Mateusza $z$ Krakowa ${ }^{15}$, by przyjechal do swego miasta rodzinnego i by $z$ ich ramienia uczestniczył — jak można się domyślać — przy kładzeniu podwalin pod odnowę podupadłej wszechnicy krakowskiej.

Z pośrednich przekazów źródłowych, jakimi są Księgi rachunkowe miasta Krakowa ${ }^{16}$, wynika, że od roku 1391 w pracach zmierzających do odnowienia podupadłego studium krakowskiego brał udział także prowincjał dominikanów z klasztoru św. Trójcy ${ }^{17}$.

Przy kolebce odradzającego się studium generalnego i dojrzewającej idei założenia wydziału teologii czuwał także światły przedstawiciel starego rodu polskiego i wysoki dygnitarz państwowy. Był nim kasztelan krakowski Jan z Tęczyna. O jego obecności jednak nie zadecydowało tylko pochodzenie ro-

${ }^{14} \mathrm{M}$. Kow alczy k, Krakowskie mowy uniwersyteckie z pierwszej połowy XV wieku, Wroclaw 1970, s. 36, 95 - 97, 120-122, $137-138,150,154,155,167,168,169,181,182$.

15 Z. Kozłowska-Budkowa, Odnowienie Jagiellońskie..., s. 37; A. L. S za frański, Mateusz z Krakowa. Wstęp do badań nad życiem i twórczościq naukowq, „Materiały i Studia Zakładu Historii Filozofii Starożytnej i Sredniowiecznej” 8:1967 s. $32-33$.

16 Andrzej z Regensburga w swojej Kronice z około 1450 r. podał, że król Władysław Jagiełło, chcąc odnowić Studium Generale, zawezwal Mateusza do Krakowa: „Erigebat studium generale in Cracovia quod etiam fecit et hoc principaliter per magistrum Matheum [...] quem ad hoc specialiter vocavit eo quod de Cracovia esset oriundus" (K. Höfle r, Geschichtsschreiber der Husitischen Bewegung in Böhmen, Bd. 2, w: Fontes rerum Austriacarum. Oesterreichische GeschichtsQuellen. Erste Abteilung, Bd. 2, Wien 1856, s. 433); zob. A. L. Szafrańs ki, Mateusz z Krakowa..., s. $28-29$.

Rajcy miasta Krakowa ,promisserunt [...] dare literam super XL marcis census [...] ipsi domino Matheo pridem per prefatos Consules benevole donatis [...] et quumcunque idem dominus Matheus Cracovie moram traxerit ad tempora dumtaxat vite persolwendis" (Najstarsze ksiegi i rachunki miasta Krakowa od r. 1300 do 1400, wyd. F. Pie k osińs ki, J. S zu j s ki, w: Monumenta medii aevi historica res gestas Poloniae illustrantia, t. 4, Kraków 1878, s. 166; por. też s. 2, 229, 231, 233). Por. A. L. Szaf rańs ki, Mateusz z Krakowa..., s. 33. W roku 1391 od rajców krakowskich honorarium poza Mateuszem Krakowa otrzymali: kasztelan krakowski Jan z Tęczyna, „pan doktor”, którego chyba należy identyfikować z Piotrem Wyszem, oraz prowincjał z klasztoru św. Trójcy: „Honores 1391 [...] Item XVI gr. XII den. pro vino dato domino provinciali ad sanctam Trinitatem. Item VIII gr. pro vino dato domino doctori. Item V gr. pro vino dato domino Cracoviensi [...] Item XXII $1 / 2$ gr. pro octo ollis vini dati domino Cracoviensi. Item X gr. minus VI denar. pro pellis datis magistro Matheo [...] Item 1/2 marc. I gr. pro vino dato magistro Matheo et Johanni de Tanczhin. Item XI gr. datos magistro Matheo pro mutone. Item X gr. pro III ollis vini datis domino Cracoviensi" (Najstarsze księgi..., s. 231). Por. M. G ę b a rowi cz, jw., s. 49, 50.

${ }^{17} \mathrm{~W}$ rachubę mógłby wchodzić Piotr Wasserrabe, Jakub z Nowego Dworu w Czechach i Franciszek Oczko, który jako jedyny Polak wykładał od roku 1379 w Studium Generale w Cambridge i później zostal lektorem w krakowskim studium dominikańskim; por. M. Gę b a rowicz, jw., s. $50 \mathrm{n}$. 
dowe i piastowane stanowisko w państwie, lecz także fakt, że był on zaufanym doradcą Jadwigi. Już z tego można wnioskować, że podejmowane w roku 1390 i 1391 przedsięwzięcia, zmierzające do erygowania w Krakowie czerowydziałowego studium generalnego, odbywały się za wiedzą i zgodą królowej Polski.

Przypuszczenie to potwierdza obecność Piotra Wysza z Radolina, będącego przy boku królowej Jadwigi, przynajmniej w okresie zimy i wiosny 1391 roku ${ }^{18}$. Jako doktor obojga praw, były wykładowca Uniwersytetu Padewskiego i protonotariusz apostolski, ten zdyscyplinowany i energiczny Wielkopolanin zajął się wnet kierowaniem biegu spraw kulturalnych i kościelnych w stolicy Polski. Być może, że to właśnie dzięki jego niewyczerpanej energii i dalekosiężnym horyzontom uświadamiana od czasu do czasu u niektórych przedstawicieli społeczeństwa polskiego idea odnowienia podupadłego studium generalnego i uruchomienia czwartego fakultetu, tj. teologii, nabrała realnych kształtów. Będąc doradcą Jadwigi i pozostając w dobrych stosunkach z zakonami krakowskimi i z radą miasta stołecznego, znając przy tym dobrze Mateusza z Krakowa, można przypuszczać, że to Piotr Wysz i Jan z Tęczyna ujęli w swoje ręce ster dalszych poczynań związanych z odradzającym się studium generalnym. Jako doradcy cieszący się zaufaniem młodej królowej Polski, nie mieli chyba trudności w rozpaleniu w jej szlachetnej duszy ognia dla tego wzniosłego celu i wspaniałego przedsiewzięcia, zwłaszcza jeżeli przed nią roztoczyli perspektywy szerzenia wiary chrześcijańskiej w obrządku łacińskim na Wschodzie i wysunęli podniesienie poziomu oświaty w Polsce i Litwie, jako dodatkowy czynnik zespolenia odrębności narodowych rozległego państwa.

Mimo że Jadwiga była pełnoprawnym królem Polski, sfinalizowanie tej sprawy na arenie międzynarodowej wymagało zgody Władysława Jagiełły, który był także koronowanym królem i stanowił faktyczną siłę polityczną. Do Jagiełły, zajętego sprawami politycznymi i umacnianiem militarnej potęgi państwa, a przy tym nie posiadającego chyba wystarczającego rozeznania w zakresie form uniwersyteckiej kultury umysłowej, trafiono za pośrednictwem uprzednio zjednanej Jadwigi. Z relacji bowiem cytowanego już teologa Franciszka z Brzegu wynika, że „prośbami i argumentami przekonana śp. królowa skłoniła króla do rozwinięcia fundacji tego uniwersytetu, która już poprzednio zaczęta w czasach króla Kazimierza, ale przez śmierć jego przerwana, dokonała się ostatecznie przez odnowienie wszechnicy"19. Chociaż Jagiełło nie był skory do przejmowania obcych decyzji, to jednak dla swojej pięknej, rozsądnej i niezwykle wysokiej kultury moralnej żony, jak to podał naoczny świadek Stani-

${ }^{18}$ S. Ki ja k, Piotr Wysz, biskup krakowski, Kraków 1933, s. 10.

19 „Ad cuius preces et motiva, Domina Regina bone memorie plurimum mota, movit Dominum Regem ad prosequendum illam Universitatem, que antea temporis Domini Regis Cazimiri erat inchoata, sed per mortem eius interrupta, tandem invocacione Universitatis facta" ( F r a n ciszek z B rzegu, Sermo de mortuis, BUW I Q 381 k. 144; cytuję za: M. G ę b a row icz, jw., s. 45 -46 , przypis 53). 
sław ze Skarbimierza ${ }^{20}$, zdobywał się na iście rycerskie ustępstwa. Tak stało się też w omawianym przypadku. I w ten sposób sprawa uruchomienia w Krakowie studium generalnego $\mathrm{z}$ wydziałem teologii na czele przeszła $\mathrm{w}$ ręce obojga monarchów, zasiadających na tronach na Wawelu. Teraz już nic nie stało na przeszkodzie, ażeby król i królowa postarali się o oficjalne papieskie zezwolenie. Uznając ważność uprzedniego zatwierdzenia papieskiego na trzywydziałowe studium, wystąpili oni już tylko z prośbą o zgodę na fundację Wydziału Teologii. Nie jest wykluczone, że wzorując się na suplice Kazimierza Wielkiego, jagiellońska para królewska pragnęła także, żeby kanclerstwo przyszłej uczelni sprawował kanclerz państwowy. Za życia biskupa Jana Radlicy, który sprawował także funkcję prowincjonalnego kanclerza koronnego, sprawa kanclerstwa uniwersyteckiego nie miała większego znaczenia. Być może, że tak zredagowaną prośbę królewską nawet zabrał udający się w lecie 1391 roku do Włoch Piotr Wysz, który przez krótki czas był chyba kanclerzem Jadwigi i który w ostatnich miesiącach tego roku przebywał właśnie w kurii rzymskiej21.

Niesprzyjające okoliczności zewnętrzne, spośród których trzeba wymienić przynajmniej intrygi krzyżackie i niechęć ze strony pobliskich uniwersytetów w Pradze i Wiedniu, opóźniały z pewnością wydanie zatwierdzenia papieskiego. W roku 1396, gdy trwające od dziesięciu lat niekorzystne stosunki polityczne nieco się poprawiły, początkodawcy nowej dynastii królewskiej w Polsce wznowili w kurii rzymskiej swoje uprzednie starania o utworzenie Wydziału Teologicznego w Krakowie ${ }^{22}$. Tym razem interwencja okazała się skuteczna. Dnia 11 stycznia 1397 roku papież Bonifacy IX wydał od dawna oczekiwaną i tak bardzo upragnioną bullę zatwierdzającą suplikę królewską na erygowanie Wydziału Teologii w istniejącym już studium generalnym w Krakowie. Przypuszczalnie dopiero na wiosnę tegoż roku ten ważny dokument papieski znalazł się w stolicy Polski. Jego adresatami byli Władysław król i Jadwiga królowa Polski ${ }^{23}$. Czyniąc zadość ich usilnym i ponawianym prośbom, papież Bonifacy IX raczył powagą apostolską postanowić i zarządzić, ażeby w studium generalnym w Krakowie mogła być nauczana teologia ${ }^{24}$. Chociaż przed ogłoszeniem tej bulli papieże wydali szereg zezwoleń na założenie wyższych uczelni z Wydziałem Teologii, to jednak należy uznać za wyjątkowe wyróżnienie i po-

20 „Widzieliśmy, jak była rozumna w radzie, przezorna w sprawach, jak pilnie starała się zachować, co do korony polskiej należało. Widzieliśmy i znaliśmy, jak była pięknego lica, jak szlachetnego rodu, jeszcze szlachetniejszych postępków; lubo na wysokiej godności jak była w duchu pokorna" (Stanisław ze Sk arbimierza, Mowa pogrzebowa, cytujęza: M. Gę ba rowicz, jw., s. 11).

${ }_{21} \mathrm{~S}$. Kijak, jw., s. 10.

22 Z. Kozłow s k a - B u d k ow a, Odnowienie jagiellońskie..., s. 40.

23 Bulla papieża Bonifacego IX erygująca Wydział Teologiczny na Uniwersytecie Krakowskim w tłumaczeniu polskim i ponownej edycji ukazała się w: „Analecta Cracoviensia” 9: 1977 s. $7-8$.

24 „Non igitur huiusmodi supplicationibus inclinati auctoritate apostolica tenore presentium statuims et etiam ordinamus, quod in ipsa civitate exnunc inantea perpetuis futuris temporibus sit ac esse valeat etiam in eadem theologia huiusmodi studium generale" (tamże, s. 7). 
czytać jako wyraz szczególnej łaski papieskiej nadanie nowo utworzonemu Wydziałowi Teologii w Krakowie takich samych uprawnień, jakie posiadał stary fakultet w Paryżu, stanowiący niedościgniony autorytet naukowy w tej dziedzinie wiedzy 25 .

Zdawać by się mogło, że gdy po długich, ponawianych staraniach i tęsknotach światłych jednostek społeczeństwa osiągnięto ten epokowy sukces w historii szkolnictwa i teologii w Polsce, zapanowała powszechna radość i zaspokojenie naukowych aspiracji. Tymczasem właśnie wtedy doszło do próby wygórowanych ambicji, do gry sił politycznych, do rywalizacji stronnictw społecznych, a nawet do zmagań władzy królewskiej i lokalnej władzy kościelnej; partykularne interesy ich doradców sprawiły, że naprzeciwko siebie znowu stanęli król Polski i biskup krakowski. Iskrą zapalną stała się ta sama sprawa, która była zarzewiem sporu między królem Kazimierzem Wielkim a biskupem krakowskim Bodzantą przy erygowaniu studium generalnego w 1364 roku.

Jeżeli nie spory, to przynajmniej dyskusje na temat przyszłego kanclerstwa odnawianego studium generalnego z wydziałem teologii na czele musiały trwać przynajmniej od 1393 roku i być znane w Stolicy Apostolskiej, skoro bulla papieża Bonifacego IX nie dosyć jednoznacznie określiła, kto ma stać na jego czele. Dyplomatyczny wybieg, że na czele studium generalnego ma stać ten, który „dotąd i od dawna stał na czele Studium"26, w lokalnych uwarunkowaniach polskich pozwoliło na dwojaką interpretację. Petycja królewska, dotąd nie odnaleziona, nie przewidywała widocznie takiego rozwiązania kanclerstwa, skoro wydana bulla papieska uraziła dumę monarchy potężnego państwa i jego możnych doradców polskich. Pamiętać jednak należy o tym, że chociaż w średniowieczu władcy świeccy fundowali wyższe uczelnie, to jednak ich kanclerstwo papieże woleli oddawać pod nadzór lokalnych biskupów niż w ręce przedstawicieli władzy świeckiej. Być może, że do tego doszły jeszcze dyplomatyczne zabiegi ambitnego protonotariusza Kościoła rzymskiego i biskupa krakowskiego, Piotra Wysza. W okresie, gdy był on tylko doradcą i kanclerzem osobnej kancelarii Jadwigi, mógł przy redagowaniu (1392) supliki do papieża nawet zgodzić się na oddanie kanclerstwa przyszłej uczelni krakowskiej w ręce kanclerza państwowego. Zostawszy przy końcu 1392 roku z woli Jadwigi biskupem krakowskim, postawił sobie za cel wzmocnienie dyscypliny i podniesienie poziomu oświaty wśród kleru. Wraz z biskupstwem krakowskim nie otrzymał on wszakże kanclerstwa prowincjonalnego, jakie posiadali jego poprzednicy. Funkcję tę przejął wielki kanclerz koronny, którym od roku 1385 do 1406 był Zaklika z Mydlnik i Międzygórza. Piotrowi Wyszowi, mającemu

25 „Et nihilominus de uberioris dono gratie concedimus, quod studentes et regentes pro tempore in ipso studio in eadem theologia, ac bacallariatus, licentie vel doctoratus gradum ibidem suscipientes, omnibus privilegiis, libertatibus, prerogativis et indulgentiis gaudeant et utantur, quibus quacunque auctoritate concessis in eadem theologia studentes, egentes et similes gradus Parisiis suscipiens gaudent ac etiam quomodolibet potiuntur" (tamże).

${ }^{26}$ „Studium generale, cui presit is, qui eidem studio hactenus prefuit ab antiquo" (tamże). 
dzięki swojej dłuższej pracy dobre stosunki także w kurii rzymskiej, dokonanie zmiany petycji królewskiej nie nastręczało większych trudności. Przy tym nie tyle występował on przeciwko Władysławowi Jagielle, a tym bardziej Jadwidze, ile przeciw swoim rywalom stojącym za plecami królewskimi, zwłaszcza wielkiemu kanclerzowi koronnemu, pragnącemu kanclerstwa uniwersyteckiego dla siebie.

Do nie rozwiązanego definitywnie problemu kanclerstwa mogła dojść jeszcze sprawa chrystianizacji ziem północno-wschodnich. Wydaje się mało prawdopodobne, by Jagiełło, a zwłaszcza królowa Jadwiga - w tym czasie już dojrzała niewiasta, posiadająca skrystalizowane ideały religijne, wśród których uchrześcijanienie ziem litewskich zajmowało centralne miejsce — nie poruszyli tego ważkiego argumentu w swoich staraniach o zgodę papieską na założenie wydziału teologicznego w Krakowie. Tymczasem bulla papieska, nie chcąc zapewne wejść w konflikt ze stojącym u szczytu swej potęgi Zakonem krzyżackim, przemilczała zupełnie sprawę misyjną.

W miejscowościach, gdzie powstały studia generalne, straciły na znaczeniu szkoły katedralne jako ośrodki wykształcenia teologicznego, stając się często tylko szkołą nauki języka lacińskiego. Z tym szedł w parze spadek prestiżu scholastyka katedralnego jako kierownika szkoły katedralnej i jako osoby odpowiedzialnej za szkolnictwo w całej diecezji. Z tego zdawał sobie sprawę ambitny scholastyk krakowski Wojciech Jastrzębiec z Rytwian, którego wykształcenie uniwersyteckie nie jest znane. $Z$ racji sandomierskich powiązań miał on możnego protektora w osobie wielkiego kanclerza koronnego Zakliki z Mydlik i Międzygórza. O ile biskup Piotr Wysz był gorącym orędownikiem szybkiego uruchomienia czterowydziałowego studium generalnego, o tyle podległy mu scholastyk Wojciech Jastrzębiec - wydaje się - nie był tym wcale zainteresowany, a może nawet hamował tego rodzaju poczynania.

Odmienne koncepcje, dotyczące oficjalnego uruchomienia studium generalnego $\mathrm{z}$ wydziałem teologicznym przybrały na sile wiosną 1397 roku i były dobrze znane monarchom królującym na Wawelu. Król Jagiełło, nie mający wystarczającego rozeznania w uniwersyteckiej kulturze umysłowej, pod wpływem swoich doradców odmówil materialnego wsparcia i oficjalnego otwarcia tego studium. Co gorsze, biskup Piotr Wysz popadł w niełaskę królewską. Sytuacja pogorszyła się jeszcze bardziej, gdy królowa Jadwiga stanęła po stronie swego męża. Biskup Wysz stracił też u niej zaufanie. Sprawa bytu przyszłego wydziału teologii stała się wprost tragiczna, kiedy królowa za podszeptem wymownego czeskiego cystersa Jana Sczekny, niegdyś wygłaszającego kazania w Wyszehradzie i w kalipcy Betlejemskiej w Pradze ${ }^{27}$, a od około 1394 nadwornego kaznodziei w Krakowie ${ }^{28}$, zdecydowała się na ufundowanie w Pradze

${ }^{27}$ F. B a r toś, Postylla doktora Jana Stekný, „Sobótka” 6 : 1951 s. 15.

${ }^{28}$ W. Ma ci e j e w s k a, Jadwiga królowa Polski, Kraków 1934, s. 136. 
specjalnego kolegium, które by przygotowywało Litwinów do zadań misyjnych i duszpasterskich w ich kraju. Na zorganizowanie tego kolegium przeznaczyła niebagatelną sumę trzech i pół tysiąca grzywien ${ }^{29}$. Głównym realizatorem tego przedsięwzięcia i pośrednikiem między Jadwigą a mieszczanami praskimi stał się Jan Sczekna ${ }^{30}$; jadąc w czerwcu lub na początku lipca 1397 roku do Pragi, zabrał on na razie chyba tylko jedną siódmą wspomnianej sumy pienię$\mathrm{dzy}^{31}$. Podtrzymywane przez Sczeknę zaangażowanie królowej Jadwigi ${ }^{32}$ co do ufundowania specjalnego kolegium dla Litwinów spotkało się z nadzwyczaj życzliwym przyjęciem w środowisku praskim, które już w roku 1364 odnosiło się z niechęcią do królewskiego zamiaru zorganizowania uniwersytetu w Krakowie i wcale nie było zainteresowane jego późniejszym odnowieniem. W nadzwyczaj bowiem szybkim tempie, bo już 20 lipca 1397 roku, król czeski Władysław IV wydał przywilej fundacyjny ${ }^{33}$. Usunięcie Andrzeja Łaskarza z końcem lipca tegoż roku z posady kanclerza królowej Jadwigi, a był on krewnym Piotra Wysza, i obsadzenie tego stanowiska przez rywala biskupa krakowskiego, podległego mu dotąd scholastyka Wojciecha Jastrzębca, będącego zaufanym króla Jagiełły i przypuszczalnie popieranym przez kanclerza koronnego Zaklikę z Międzygórza - były wyrazem paraliżowania, a nawet unicestwienia akcji zmierzającej do uruchomienia wydziału teologii w Krakowie. Przygotowany przez Wojciecha Jastrzębca, kanclerza królowej Jadwigi, dokument fundacji Kolegium Litewskiego w Pradze ukazał się już 10 listopada 1397 roku $^{34}$. Podkreślone w nim apostolskie dzieło chrystianizacji Litwy zmniejszyło konieczność organizowanego wydziału teologii w Krakowie i oznaczało, jeżeli nie całkowitą odmowę, to przynajmniej zmiejszenie wsparcia materialnego ze strony pary królewskiej. Porzucenie myśli o forsowaniu sprawy uruchomienia krakowskiego wydziału teologii na rzecz Kolegium Litewskiego w Pradze nie przyszło królowej Jadwidze jednak łatwo, skoro dopiero po wielu bezsennych

${ }^{29}$ Z. Kozlow sk a-B u d k ow a, Odnowienie Jagiellońskie..., s. 41.

${ }^{30} \mathrm{C}$. Z a wodzińs k a, Kolegium królowej Jadwigi przy Uniwersytecie Karola w Pradze i jego pierwszy statut, „Zeszyty Naukowe Uniwersytetu Jagiellońskiego. Prace Historyczne” 56 : $1962 \mathrm{z}$. 9 s. 21.

${ }^{31}$ Z. Kozłows k a-B u d k ow a, Odnowienie Jagiellońskie..., s. 41.

${ }^{32}$ Z. Perzanowski, opierając się na relacji Jana Długosza, uważa, że w związku z fundowanym Kolegium Litewskim królowa Jadwiga nawet osobiście udała się do Pragi (zob. Z. Pe r z a n ow ski, Kanonik krakowski ks. Jan Długosz o królowej Jadwidze, „Analecta Cracoviensia” 12:1980 s. 204). Podstawą tego twierdzenia stał się następujący tekst Jana Długosza: „Królowa polska Jadwiga, pragnąc wzmocnić zaszczepioną na Litwie świeżo przez króla polskiego Władysława ze szczerej pobożności religijności prawdziwą wiarę, dziesiątego grudnia zakłada na będącym wówczas w rozkwicie uniwersytecie praskim, specjalne kolegium dla studentów pochodzących z Litwy, żeby się w tym domu zbierali. Zakupiła murowany dom pelen wygodnych izb, sal i pracowni na starym mieści w Pradze, położony niedaleko pałacu królewskiego, w pobliżu pałacu królewskiego, w pobliżu pałacu królowej. Kolegium to bowiem jest nazywane pospolicie do dnia dzisiejszego Kolegium czyli domem królowej, sławiąc godny pamięci czyn swej fundatorki” (J. Dł u g o s z, Roczniki czyli Kroniki sławnego Królestwa Polskiego, przekł. J. Mruków na, t. 6, Warszawa 1981, s. 290).

${ }^{33}$ Zob. niżej aneks 1 .

${ }^{34}$ Zob. niżej aneks 2. Nadto por.: M. Sva tos̀, Litewska kolej Pražská Univerzity (1397 1622), [w:] Praha-Vilnius Univerzita Karlova, Praha 1981, s. 19-32; K. Sza j n och a, Jadwiga i Jagietto 1374 - 1413. Opowiadania historyczne, t. 3, Warszawa 1969, s. 365 n. 
nocach i długich rozmyślaniach, jak to wynika $\mathrm{z}$ arengi ${ }^{35}$ — opowiedziała się za tym alternatywnym rozwiązaniem.

Niełaska króla Jagiełły, zaangażowanie się królowej Jadwigi w fundację Kolegium Litewskiego w Pradze i brak należytego wsparcia nawet ze strony ówczesnej kapituły krakowskiej utrudniały, a nawet wręcz przekreślały mozoIne wysiłki biskupa Piotra Wysza na rzecz odnowienia wydziału teologii w Krakowie. W tym wprost beznadziejnym położeniu przyszło mu działać przez jakiś czas w niełasce królewskiej i niemalże w osamotnieniu. Zdawał on sobie sprawę jednak z tego, że bez zgody fundatorów nie może dokonać oficjalnego otwarcia studium generalnego wraz z wydziałem teologii. Studium to mogło jednak prowadzić działalność dydaktyczną w dotychczasowym, ograniczonym zakresie. Ażeby ją poszerzyć o teologię, trzeba było znaleźć profesora. W zaistniałych okolicznościach nie można było liczyć na sprowadzenie profesora teologii z Pragi.

W tej dotkliwej izolacji ów niestrudzony animator podupadłego studium generalnego miał moralne wsparcie wśród przebywających w Krakowie magistrów filozofii i doktorów prawa. Biskup Wysz nie szczędził chyba nawet osobistych funduszy. $\mathrm{Z}$ materialnym wsparciem pośpieszyła znowu rada ówczesnego miasta stołecznego. Skorzystał z niego Mateusz z Krakowa, który rzucił nawet heidelberskie berło rektorskie oraz funkcję książęcego kapelana i pośpieszył niezwłocznie do Krakowa, by w swoim rodzinnym mieście organizować nauczanie teologii na poziomie wyższym. Trwało to chyba od 1397 do 1399 roku, za co otrzymywał on na mocy uchwały rajców krakowskich 40 grzywien rocznie, co stanowiło według Kazimierzowskiego aktu erekcyjnego najwyższą stawkę uposażenia profesorskiego. Prawdopodobnie w wyniku dydaktycznej działalności Mateusza z Krakowa przed 16 kwietnia 1399 roku wypromowany zostal Jan Isner ${ }^{36}$.

W tym krytycznym okresie, w którym ważyły się losy dalszej egzystencji nie tylko wydziału teologii, lecz także całej wszechnicy krakowskiej, uruchomienie ich faktycznej działalności dydaktycznej było już nielada sukcesem. Jego pełne uwieńczenie nie mogło się odbyć bez zjednania sobie przychylności królewskich fundatorów. Dla pomyślniejszego biegu tych spraw doniosłe znaczenie miała w 1398 roku nominacja Jana z Tęczyna ochmistrza Jadwigi. On prawdopodobnie ułatwił Piotrowi Wyszowi znowu dostęp do królowej. Nie wiadomo, czyją zasługą było przekonanie jej o tym, że o wiele większe znaczenie ma sprawa rychłego oficjalnego otwarcia w Krakowie studium generalnego z wydziałem teologii na czele niż dalsze finansowanie Kolegium litewskiego w Pra-

${ }^{35}$ A. Strze leck a, Jadwiga Andegaweńska Anjou (1374 - 1399), [w:] PSB t. 10, Wrocław 1962 , kol. 296.

36 Repertorium Germanicum, Bd. 2, bearbeitet von. G. Telle n b a ch, Berlin 1896, kol. 675; M. M r k ow s ki, Spis osób dopuszczonych do wyktadów i do katedry na Wydziale Teologii Uniwersytetu Krakowskiego w XV w. , „Materiały i Studia Zakładu Historii Filozofii Starożytnej i Średniowiecznej" $4: 1965$ s. 214. 
dze. Poza Janem z Tęczyna i Piotrem Wyszem w rachubę mógłby jeszcze wchodzić długoletni oficjał krakowski i późniejszy biskup wileński Mikołaj z Gorzkowa oraz Mateusz z Krakowa, który w tym czasie z kolacji królewskiej otrzymał kilka prebend.

Wydaje się, że królowa Jadwiga już w roku 1398 zaniechała dalszego finansowania fundacji Kolegium Litewskiego w Pradze. Czerpiąc ze skarbu królewskiego, wspierała w pierwszym rzędzie teologów ${ }^{37}$. Poza Mateuszem z Krakowa wypada jeszcze wymienić Jana Isnera ${ }^{38}$, Jana Sczeknę ${ }^{39}$ i Mikołaja Wiganda z Krakowa ${ }^{40}$. Fundusze łożone tak przez królową Jadwigę, jak i przez biskupa Wysza nie wystarczały wszakże na oficjalne otwarcie czterowydziałowego studium generalnego w Krakowie. Najważniejsze jednak było to, że sprawa ta weszła na realne tory i że z każdym dniem zbliżał się doniosły moment ziszczenia się nadziei i aspiracji wielu osób.

Pozycja ludzi niezainteresowanych ani oficjalnym otwarciem studium generalnego w Krakowie, ani uruchomieniem jego wydziału teologicznego była nadal bardzo silna. Wojciech Jastrzębiec był przecież kanclerzem królowej Jadwigi, zaufanym doradcą króla Jagiełły, z którego polecenia załatwiał sprawy w kurii rzymskiej. O jego mocnej pozycji nie tylko na dworze królewskim, lecz także u papieża świadczy najlepiej fakt, że to właśnie jego, a nie biskupa krakowskiego czy arcybiskupa gnieźnieńskiego Bonifacy IX wyznaczył na chrzciciela mającego się narodzić dziecka Jadwigi i Władysława. Dopiero zamianowanie w dniu 5 maja 1399 roku Wojciecha Jastrzębca biskupem poznańskim zmusiło go do opuszczenia Krakowa. Dzięki temu jego „awansowi” w najbliższym otoczeniu królowej poza Janem z Tęczyna mógł swobodniej przebywać Piotr Wysz. Zabłysnął znów promień nadziei na oficjalne otwarcie studium generalnego $\mathrm{z}$ wydziałem teologii na czele.

W tym pomyślniejszym okresie odradzania się życia uniwersyteckiego w Polsce dzień 17 lipca 1399 roku wstrząsnął niemal całym spoleczeństwem polskim. Była to niespodziewana śmierć młodziutkiej królowej Polski, Jadwigi. Smierć tej, która miała stać się matką nowej dynastii, zachwiała nawet podstawami potężnego państwa, opartego na uni polsko-litewskiej. Odejście oddanej współfundatorki Uniwersytetu Krakowskiego pogrzebało, przynajmniej na jakiś czas, nadzieje tych, którzy liczyli na jego szybkie oficjalne otwarcie.

37 „Obtenta hac suprema liberalitate Bonifacii, pro Facultate Theologica, eandem ordinandam assignatis ex thesauro Regio pro Lectoribus stipendiis donec se alia occasio daret, que cerciora omnibus Professoribus salaria providerentur, Joanni Isnero Sacrae Theologiae Doctori Hedvigis committit, brevi quoque in urbem opera sua Academiam transferendam promittens" (M R a d ym iń s k i, Annalium almae Academiae Cracoviensis centuria I, Bj $226 \mathrm{k}$. 18 v); por. J. A. P u t a n owi cz, Życie, cuda i dzieje kanonizacji s. Jana Kantego, Kraków 1780, s. 229; M. G ę b a rowi cz, jw., s. 70 .

38 J. N. F i jał e k, Studia do dziejów Uniwersytetu Krakowskiego i jego Wydziatu Teologicznego w XV wieku, Kraków 1898, s. 60.

${ }^{39}$ Tamże, s. 67.

40 Tamże, s. 81. 
Rozpacz po niezwykłej i zmarłej w opinii świętości dwudziestopięcioletniej królowej wyryła niezatarte piętno w nastrojach społecznych i w świadomości różnych warstw społeczeństwa. Pielgrzymki do jej grobu i wznoszone przez lud modły cementowały szlachetne dążenia tkwiące w narodzie. Ta atmosfera przyhamowała rozgrywki personalne doradców królewskich, zwłaszcza wielkiego kanclerza koronnego Zaklikę z Międzygórza, i ułatwiła, a nawet przyśpieszyła wykonanie ostatniej woli zmarłej królowej. Aktem tym (nie wiadomo, czy pisanym czy tylko ustnym) zaleciła wierność poddanych wobec króla Jagiełły i przeznaczyła część posiadanych klejnotów i złota na uposażenie studium generalnego w Krakowie. $Z$ tych środków wykonawcy jej testamentu biskup Piotr Wysz i kasztelan Jan z Tęczyna zakupili dom znajdujący się na ówczesnym zaułku żydowskim (vicus Judeorum), dzisiaj na rogu ulic Sw. Anny i Jagiellońskiej ${ }^{41}$. W domu tym król Jagiełło uroczystym aktem wydanym dnia 22 lipca 1400 roku, ustanowił Collegium Almae Universitatis Studii Cracovien$s i s^{42}$, najpierw nazywane Kolegium Królewskim lub Kolegium Artystów, a od 1449 roku Kolegium Większym (Collegium Maius). Pozostawione przez zmarłą Jadwigę dobra doczesne stworzyły więc dopiero lepsze warunki lokalowe do szerszej działalności dydaktycznej czterowydziałowego studium generalnego w Krakowie. Jego nowo ukonstytuowana społeczność profesorska, nie czekając na akt fundacyjny króla Jagiełły, wybrała rektora, którym został doktor prawa Stanisław ze Skarbimierza ${ }^{43}$. Założył on metrykę uniwersytecką, w której jako pierwszy figuruje Władysław, król Polski i fundator Uniwersytetu, jako drugi występuje Piotr Wysz, biskup krakowski i kanclerz studium generalnego ${ }^{44}$. Z kolei następuje zapis magistra Mikołaja z Kurowa, biskupa włocławskiego i późniejszego arcybiskupa gnieńskiego, Jana z Tęczyna, kasztelana krakowskiego i wielkiego dobrodzieja uczelni, i Klemensa z Moskrzewa, podkanclerzego i promotora Uniwersytetu Krakowskiego. Godne uwagi jest to, że założona w 1400 roku przez rektora krakowskiej korporacji uniwersyteckiej

${ }^{41}$ Z. Kozłow ska - Bu dk ow a, Odnowienie Jagiellońskie..., s. 41.

42 „Sub anno Domini millesimo quadringentesimo Collegium almae Universitatis Studii Cracowiensis est institutum per serenissimum invictissimum principem Wladislaum Dei gracia regem Poloniae etc. in ipso die sancte Marie Magdalene" (BJ 258 s. 4).

„Aby zaś doktorowie, mistrzowie, licencyaci, bakałarze i studenci rzeczonego uniwersytetu krakowskiego, swoje wykłady, ćwiczenia i czynności naukowe swobodniej mogli i zdołali odbywać, na mieszkanie mistrzów, i na codzienne i powszechne zbieranie się studentów i scholarów dom nasz [...] postanowiliśmy wyznaczyć [...]; a dom ten uniwersytetowi rzeczonemu oddajemy na własność, do niego wcielamy i przyłączamy na zawsze i na wieki, nic w nim prawa i dziedzictwa sobie i następcom naszym nie zastrzegając" (S. K rz yża n ow ski, Poselstwo Kazimierza Wielkiego do Awinionu i pierwsze uniwersyteckie przywileje, Kraków 1900, s. 109-110; tekst łaciński w: KodUJ 1 s. 28).

${ }_{43}$ „Anno Domini $\mathrm{M}^{\circ} \mathrm{CCC}^{\circ}$ die XXIIII mensis Julii sub venerabili viro Magistro Stanislao decretorum doctore, Rectore universitatis primario studii Cracoviensis" (Album studiosorum Universitatis Cracoviensis, ed. A. Chmi e 1, t. 1, Cracoviae 1887, s. 1).

44 „Hii sunt instytulati: Et primo Serenissimus princeps et dominus Wladislaus dei gracia Rex Polonie, fundator huius venerabilis universitatis et dator piissimus. Item Reverendissimus dominus Petrus Dei gracia Episcopus Cracoviensis, utriusque Juris doctor, Cancellarius generalis studii Cracoviensis" (tamże). 
metryka przyznaje godność kanclerza biskupowi krakowskiemu, a podkanclerzemu królestwa daje tylko funkcję promotora ${ }^{45}$. Zauważyć wypada, że wśród dostojników kościelnych i państwowych zabrakło biskupa poznańskiego Wojciecha Jastrzębca i wielkiego kanclerza koronnego Zakliki z Międzygórza.

Tę działalność nowej korporacji z rektorem na czele pod względem prawnym usankcjonowało dopiero oficjalne wydanie przez króla Jagiełłę przywileju fundacyjnego, co nastąpiło w dniu 26 lipca 1400 roku i było wydarzeniem najważniejszym. Powołując się na zatwierdzenie papieża Bonifacego IX, król Władysław Jagiełło ufundował w Krakowie studium generalne dla nauki wszystkich dozwolonych dziedzin wiedzy, a więc teologii, prawa kanonicznego i cywilnego, medycyny i umiejętności wyzwolonych ${ }^{46}$. Biskup Piotr Wysz, chcąc zaznaczyć swój związek z powołaną do życia uczelnią, wygłosił w tym uroczystym dniu wykład inauguracyjny ${ }^{47}$. Przemówił także nowy rektor, Stanisław ze Skarbimierza, kreśląc program nauczania już oficjalnie działającej uczelni ${ }^{48}$. Jej otwarcie nastąpiło, mimo że sprawa kanclerstwa uniwersyteckiego nie została definitywnie rozstrzygnięta. Podobnie jak Kazimierz Wielki ${ }^{49}$,

45 Tamże. Por. K. Mor aw ski, historia Uniwersytetu Jagiellońskiego. Srednie wieki i odrodzenie, t. 1, Kraków 1900, s. 82.

46, „Non dubitantes id ipsum subditis regni praedicti et terrarum nostrarum salubriter profuturum, in Cracovia civitate nostra locum ubi Studium vigeat generale in qualibet licita facultate, de consensu, voluntate et scientia ac indulto Sanctissimi in Christo patris domini et domini Bonifacii Dei providentia Papae IX. Sacrosanctae Romanae et universalis Ecclesiae Summi Pontificis, ipsum benigne per bullarum suarum concessionem confirmatis, utpote in theologia seu Sacrae Scripturae, Iuris canonici, Legum, Phisicae et Artium liberalium facultatibus nominandum, eligendum, constituendum, ponendum et ordinandum ac erigendum duximus et tenore praesentium facimus temporibus perpetui duratarum" KodUJ 1 s. 26).

${ }_{47}$ „Et sermo prima lecta est feria secunda post festum sancti Jacobi apostoli in decretalibus per reverendum in Christo patrem ac dominum dominum Petrum (Wysz) divina miseracione episcopum Cracoviensem, cancelarium eiusdem Studii Generalis" (BJ 258, s. 4); por. Z. Kozłows k a - B u d k ow a, Odnowienie Jagiellońskie..., s. 44.

„Magister Petrus de Radolina J. U. D. nunc Episcopus Cracoviensis ut qui olim Professor, nunc erat Cancellarius Academiae, lectionem primam legit. Ea finita gratulatus est Regni meritam apud Deum et perennem memoriam ex fundatione Academiae apud omnem posteritatem, nec desituram prius auguratus est, quam Regni Virga (quod omen Deus auferat) frangeretur. Nec enim, inquiebat, ille parcet Coronae, qui Sceptra Academiae huius infregerit.

Finita omnium per Fiat. Fiat. acclamatione, Rex initium novae Matriculae per insertionem Nominis Sui $[\ldots]$ dedit.

Sceptra deinde cum Diademate pro sigilio Rectori; Almae vero Universitati Aquilam cum Clypeo, quam Tiaratuś Praesul S. Stanislaus Martyr tenet, contulit" (M. R a d y m iński, jw., BJ 226 k. 40 v; polski przekład tego tekstu w: M. Wis zni ew s ki, Historia literatury polskiej, t. 4, Kraków 1842, s. 243; por. M. Gę b a rowicz, jw., s. 54).

${ }^{48}$ Tekst laciński znany jest z dwóch przekazów rękopiśmiennych: BJ 191 k. $357 \mathrm{v}-361 \mathrm{r}$ (s. $714-721)$ i BJ 723 k. 208 r - 212 r (s. 413-419). Przekład polski tej mowy dal M. W is z n i ewski (jw., t. 4 s. 251). Por. M. M a r k owski, Programowe założenia uniwersyteckiego nauczania w jagiellońskiej odnowie krakowskiego studium generale, „Analecta Cracoviensia” 19: 1987 s. 234 -238 .

49 „Statuimus etiam et quotienscumque aliquos Scolares in qualibet facultae per Doctores seu Magistros ad privatum examen more consueto poni contigerit, super illos Cancellarius noster Cracoviensis, qui pro tempore fuerit tamquam supremus, approbandi huiusmodi examen omnimodam habeat potestatem. Item pro habendo exercito Scolaribus Studii dominus Episcopus Cracoviensis Officialem suum in ipsa civitate Cracoviensi locare debeat, prout est locatus, ut de lectionibus Scolares ad practicam transeant ut sumant audaciam allegandi" (KodUJ 1 s. 3). 
z którym współdziałała rada miejska Krakowa ${ }^{50}$, ale sprzeciwił się papież Urban $\mathrm{V}^{51}$ - Władysław Jagiełło nie chciał oddać kanclerstwa uniwersyteckiego w ręce władzy kościelnej. Piotrowi Wyszowi jako biskupowi krakowskiemu dał on tylko stanowisko konserwatora ${ }^{52}$.

Nie ma żadnej przesady w stwierdzeniu, że nieoczekiwana śmierć zmarłej w kwiecie wieku królowej Jadwigi przyśpieszyła dzień oficjalnego i uroczystego otwarcia czterowydziełowego studium generalnego w Krakowie. Chociaż przywilej fundacyjny wydał sam król Władysław Jagiełło, to był on świadom tego, że pozostawione przez jego zmarłą żonę dobra materialne, chociaż były nie wystarczające, umożliwiły mu wydanie tego najważniejszego dokumentu. Podkreślając w nim, że krakowski Wydział Teologii będzie także służył pełnemu uchrześcijanieniu Litwy ${ }^{53}$, Jagiełło spełnił najgłębsze pragnienia serca Ja-

50 „Nos vero consules, scabini et iurati Cracovienses supradicti Rectori Universitatis, Doctoribus, Magistris, Scolaribus et aliis omnibus quorum interest saepedictis in Studio Cracoviensi moram trahentibus, omnia et singula Statuta et pacta in Studiis Bononiensi et Padwano consueta, ac per eos rationabiliter Cracoviae statuenda, promittimus perpetuo ipsis tenere et inviolabiter observare, iposque in visceribus caritatis gerentes, manutenere volumus, in suis iuribus defendere et tueri, Rectori quoque supradicto, qui pro tempore fuerit, ad compescendum rebelles, prout in praefatis privilegiis domini nostri Regis continetur, assistere fideliter et praestare consilium, auxilium et favorem. Ut autem omnia et singula praemissa perpetuis temporibus firma et illibata permaneant praesentium et futurorum memoriae sane commendata, praesentes nostras literas Magistris, Doctoribus, Rectoribus, Scolaribus et caeteris omnibus superius expressis, quorum interest, et qui pro tempore fuerint, dari mandavimus de maturo nostro et totius communitatis consilio et assensu, nostrae civitatis Cracoviensis saepedictae sigillo patenti roboratas" (KodUJ 1 s. 5-6).

51 ,Et quod legentes et studentes ibidem omnibus privilegiis, libertatibus et immunitatibus, concessis Doctoribus, legentibus et studentibus commorantibus in Studio generali gaudeant et utantur, quodque illi, qui processu temporis bravium fuerint in illa facultate, in qua studuerint, assecuti, sibique docendi licentiam, ut alios erudire valeant, ac Doctoratus seu Magisterii honorem petierint elargiri per Doctores seu Doctorem ac Magistros seu Magistrum illius facultatis, in qua examinatio fuerit facienda, Episcopo Cracoviensi, qui pro tempore fuerit, vel ecclesia Cracoviensi pastore carente, Vicario seu Officiali dilectorum filiorum Capituli ipsius ecclesiae praesentatur. Idem quoque Episcopus aut Vicarius seu Officialis Doctoribus et Magistris in eadem facultate actu ibidem regentibus convocatis, illos in his, quae circa promovendos ad Doctoratus seu Magisterii honorem requiruntur, per se vel per alium, iuxta modum et consuetudinem, qui super talibus in generalibus Studiis observantur, examinare studeat diligenter, eique si ad hoc sufficientes et idonei reperti fuerint, huiusmodi licentiam tribuat et Doctoratus seu Magisterii conferat honorem. Illi vero, qui in eodem Studio dictae civitatis examinati et approbati fuerint ac docendi licentiam et honorem huiusmodi obtinuerint, ut est dictum, extunc absque examine et approbatione alia, regendi et docendi tam in civitate praedicta, quam singulis aliis generalibus Studiis, in quibus voluerint, legere vel docere, Statutis et consuetudinibus quibuscumque contrariis, apostolica vel quacunque firmitate alia vallatis, nequaquam obstantibus, plenam et liberam habeant facultatem" (KodUJ 1 s. 7).

52 „Verum quia parum prodest libertas condere, nisi qui eas tueatur et conservet, habeatur; pro quo Studium praedictum Cracoviense in iuribus, libertatibus et Statutis efficatius conservare cupientes, Episcopum Cracoviensem, qui pro tempore fuerit, omnium et singularum libertatum, immunitatum, exemptionum et Statutorum Studii supradicti conservatorem constituimus, eique damus plenam et liberam potestatem ipsum conservandi et tuendi, libertatesque eius exequendi ac in rebelles et malefactores Studii et studentium praedictorum poenas, quas virtute praesentium vel etiam secundum Leges, Canones seu Statuta locorum meruerint, exigente ipsorum maleficio et contumacia, ratione praevia declarandi: qui etiam Episcopus cum Rectore Universitatis pecunias et salarium pro Magistris et Doctoribus distribuendi et commoda in Collegio dividendi iuxta exigentiam status et meriti cuiuslibet, plenam et omnimodam habedit facultatem" (KodUJ 1 s. 29).

${ }^{53}$ „Ex quo aeterni Regis despensatio ineffabili cuncta disponens ratione, nos de gentilitatis eduxit erroribus, et ad regalis dignitatis fastigium, quemvis nostris insufficientibus meritis, dignata est evocare, ad hoc praecipue sedula meditatione propositorum nostrum studia dirigimus, curam- 
dwigi, żywione przez nią za życia i tak pięknie wyrażone przy fundacji Kolegium Litewskiego w Pradze ${ }^{54}$, które, gdy powstało w 12 lat później, nie służyło już tym celom ${ }^{55}$.

Uniwersytet Krakowski zaczął oficjalnie działać, ale nadana przez króla Jagiełłę roczna pensja 100 grzywien była daleko nie wystarczająca ${ }^{56}$. Do tego doszły wprawdzie inne drobne nadania ${ }^{57}$, ale nie rozwiązały one sprawy uposażenia wykładowców krakowskich w pierwszym dziesięcioleciu XIV wieku. Jan Isner, który występuje jako pierwszy wśród inkorporowanych profesorów krakowskiego Wydziału Teologii i uchodzi za jego organizatora, podchwycił też chowane w sercu niegdyś przez królowe Jadwigę nadzieje, fundując w roku 1409 dla studiujących w Krakowie biednych Litwinów i Rusinów tzw. Collegium Pauperum ${ }^{58}$. Egzystencja odnowionej uczelni była jeszcze bardziej zagrożona w okresie intensywnych przygotowań do rozprawy z Krzyżakami. Pełen obaw o dalsze losy Uniwersytetu Krakowskiego był Jan Isner, gdy 22 marca 1410 roku sporządzał swój testament ${ }^{59}$. Zwycięstwo pod Grunwaldem przesądziło też o dalszym istnieniu krakowskiej uczelni.

que nostrae internae diligentiae deputamus, ut hos terrarum nostrarum Lythuaniae indigenas et subditos, praesertim quos in vetustati erroris caligine olim constituti socios tenebrarum habuimus, quosque per assumptionem sacrae fidei catholicae ad gremium sanctae matris Ecclesiae, illo volente, qui coelectia partier et terrena moderatur et dirigit, adtulimus per assuefactionem et habitudinem ac scientiam priorum operum, sine quibus ipsa fides est vacua, in lucis filios convertamus, horum tamen ope pariter et opera, quorum animos sapientiae et doctrinae plenitudo decoravit, videlicet in fundamentis et profunditatibus, scriptuarum expertorum, quorum etiam consilio thronus roboratur regius, ut eorum virtutis actibus reipublicae stabilitas semper salubribus proficit incrementis" (KodUJ 1 s. $25-26)$.

${ }^{54}$ Zob. niżej aneks 2.

55 Zob. niżej aneks 3.

56 „Caeterum pro maiori stabilimento Studii generalis Cracoviensis praenotati dignum fore arbitrantes hos, qui labores et onera sufferunt, non repelli a mercede, Doctoribus et Magistris ac Collegiatis Studii eiusdem Cracoviensis, qui fundamenta doctrinarum in eodem Studio debent erigere et lecturis ac informationibus ipsorum studentes instruere et fovere de centum marcis numeri Polonicalis ratione salarii anno quolibet animadvertimus assignandum" (KodUj 1 s. 28-29).

57 Zob. Z. Kozłow sk a-B u d k ow a, Odnowienie Jagiellońskie..., s. 47.

58 „Nos a Serenissimo Principe ac domino domino Wladislao Rege Poloniae, Litwaniaeque Principe supremo etc. domino nostro gratiosissimo, suis seriosis suscepisse regalibus in mandatis, quod una cum reverendo viro domino et Magistro Johanne Ysneri Sacrae Theologiae digno Professore aliquam domum in dicta civitate Cracoviensi pro habenda mora, immoratione et inhabitatione pauperum ac divitum undecunque, et signanter de regno et partibus Lytwanorum ac Russiae ad studendum huc venientium, deberemus inquirere et ad emendum ac comparandum alicubi invenire" (KodUJ 1 s. 75).

59 „Si autem Studium Cracoviense cadet, tunc praedicta bona cum suis fractibus universis testatus est pro uno Magistro graduato in Theologia, aut Sententiario, qui sit lector in ecclessia cathedrali Cracoviensi, et eius praesentatio spectare debet ad seniorem de armis praemissis, qui etiam sit adstrictus ad duas missas in septimana. Item specialiter praedictis dominis et Magistris Nocilao Pyser et Francisco committo domum, quam emi pro Universitate studii Cracoviensis ad usum pauperum Magistrorum, Baccalaureorum, studentium, et ad quam ante omnia, si fuerint, recipi Lithuani et Rutheni habiles ad studium theologicale et Artium, ad dilucidandam catholicam fidem, sic quod posterior domus deserviat habitationi pauperum, et anterior domus deserviat divitibus, qui censum debent his pauperibus, de quibus dictum est supra, dare. Item de censu domus anterioris debent omni anno octo marcae dari duobus aptis Lithuanis ad studium Theologiae et Artium, qui studuerint, et in domo praedicta habitationem habeant tanquam pauperes studentes. Interim autem cum dari non possunt, tunc debent istae octo marcae dari duobus pauperibus sacerdotibus et studentibus in theologia, quorum quilibet legat quatuor vicibus in septimana Requiem et 
Uniwersytet Krakowski prowadził działalność dydaktyczną, ale zatargi o kanclerstwo jego trwały nadal. W niektórych dokumentach uniwersyteckich z tego czasu Piotr Wysz występuje jako kanclerz. Poza cytowanym już Album studiosorum i zapiską o inauguracji studiów w 1400 roku $^{60}$ wymienić wypada jeszcze dokument z 14 sierpnia 1409 roku $^{61}$. Stanisław ze Skarbimierza, przemawiając podczas oficjalnej inauguracji, nazwał Piotra Wysza kanclerzem Studium Generalnego ${ }^{62}$. Profesor teologii Franciszek z Brzegu, wygłaszając kazanie na ekzekwiach zmarłego w Poznaniu (31 maja 1414) Piotra Wysza, mówił o nim jako o konserwatorze i kanclerzu Uniwersytetu Krakowskiego ${ }^{63}$. Marcin Biem z Olkusza podał w swoich notatkach historycznych, że Piotr Wysz był kanclerzem ${ }^{64}$. $\mathrm{Z}$ tej racji modliła się za niego też korporacja uniwersytec$\mathrm{ka}^{65}$. Te praktyki uniwersyteckie nie mogły nie być znane doradcom królewskim. Za ich radą Władysław Jagiełło z pewnością zwrócił się specjalnie do papieża o rozstrzygnięcie krakowskiego sporu o kanclerstwo uniwersyteckie. Pismem z 28 lipca 1410 roku papież pisański Jan XXIII potwierdził, że tę godność sprawuje każdorazowy kanclerz królewski ${ }^{66}$ i że biskupowi krakowskiemu

Vigilias cum tribus lectionibus. Si autem Studium Cracoviense defluet, extunc legavit et testatus est domum praedictam pro ecclesia Sanctae Mariae Virginis Sandomirien (KodUJ 1 s. 83 - 84).

${ }^{60}$ Zob. wyżej przypis 44 i 47.

61 „Per referendum in Christo patrem et dominum dominum Petrum Dei gratia Episcopum Cracoviensem nec non Cancellarium almae Universitatis Studii Cracoviensis..." (KodUJ 1 s. 79; dokument Jana Szafrańca i Ottona, scholastyka katedry wawelskiej, regulujący rozdział dochodów kościola św. Floriana między profesorów Uniwersytetu Krakowskiego).

62 „A qua Universitate iam procedunt fulgura in voce cherub precipui, videlicet Reverendissi$\mathrm{mi}$ in Christo patris ac domini domini Petri Dei gratia epicopi Cracoviensis ac cancellarii Studii huius generalis" (BJ 191 s. 714; BJ 723 s. 413). Zob. C. Za w od zi ń s k a, Pisma Stanisława ze Skarbimierza w kodeksach Biblioteki Jagiellońskiej, „Roczniki Biblioteczne” 4 : 1960 s. 315; Z. K ozł ow s k a - B u dk ow a, Odnowienie Jagiellońskie..., s. 46.

63 „Eo quod semper bonum aggectum benignum affatum et studiorum effectum videtur habuisse circa Universitatem istam. Bonum quidem affectum quia in principio Studii se magistris associavit et cum eis bursam posuit et onera Collegii portavit; benignum affectum quia dum conservator universitatis existeret se omnibus suppositis Universitatis benignum verbis suis exhibuit; studiosum effectu, quia Collegio eciam sepius dona spiritualia tribuit et alios ad hoc invitabat. Et cum spe remunerandi, sicut mihi constat decessit... quod merito faciemus eo quia ipse fuit dominus et pater, fautor et amicus noster graciosus. Sicut enim constat, ipse fuit diocesanus Cracoviensis et Cancellarius universitatis" (BUW I Q 381 k. 144; cytuję za: M. G ę b a row i c z, jw., s. 45 przypis 53).

64 „Hoc anno Christi, scilicet 1400, serenissimus Wladislaus rex Polonie fundavit et dotavit Studium generale Cracovie. Et eo anno per reverendissimum in Christo patrem dominum dictum Wysch Petrum episcopum Cracoviensem utriusque iuris doctorem et cancellarium Studii eiusdem prima leccio in iure canonico ipso die sancte Marie Magdalene [20. VII] est facta. Et idem reverendissimus episcopus anno sequenti, scilicet 1401, in Quatuor temporibus post Exaltacionem sancte Cracis celebravit primum examen pro gradu baccalariatus in artibus" (M. Kowalczyk, Grunwald w tradycji kaznodziejsko-kronikarskiej z końca XV wieku, „Analecta Cracoviensia” 19 : 1987 s. 273 - 274; notatka Marcina Biema w inkunabule BJ 1108 k. 228 v).

65 ,Nota modum et ordinem petendi pro benefactoribus Universitatis: primo pro spiritualibus viventibus, $2^{\circ}$ pro secularibus, $3^{\circ}$ pro defunctis [...] Item pro domino nostro episcopo Cracoviensi, cancellario huius alme Universitatis [...] Item pro domino Nicolao vicecancellario, promotore Universitatis [...]. Item pro domina regina pie memorie huius Universitatis renovatrice et benefactrice [...]" (zob. Z. Kozlow s k a-B u d k ow a, Odnowienie Jagiellońskie..., s. 88 - 89).

66 „Statuit etiam praefatus Rex, ut quotienscunque aliquos Scolares in qualibet facultate per Doctores seu Magistros ad privatum examen more consueto poni contingeret, super illos Cancellarius ipsius Regis, qui esset pro tempore, tamquam summus approbandi ipsum examen haberet omnimodam potestatem. Multa etiam alia rationabilia circa haec edidit sive statuit et ordinavit Rex 
przysługuje tylko funkcja konserwatora tej uczelni ${ }^{67}$. Zatargi trwały widocznie dalej, skoro w roku 1412 Piotra Wysza przeniesiono na biskupstwo poznańskie. Jest stanowisko zaś objął Wojciech Jatrzębiec, dołączając do tego kanclerstwo państwowe i uniwersyteckie. W ten sposób zakończył król Jagiełło kilkunastoletni spór o kanclerstwo Uniwersytetu Krakowskiego.

Sprawa uchrześcijanienia ziem północno-wschodnich królestwa polskiego, wspomniana w roku 1387 przez papieża Urbana VI w liście do Jagiełly ${ }^{68}$, a przez królowę Jadwigę zdecydowanie wyrażona (10 XI 1397) w akcie fundacyjnym Kolegium litewskiego ${ }^{69}$, sprawa podniesiona przez króla Władysława Jagiełłę (26 VII 1400) w przywileju fundacyjnym Uniwersytetu Krakowskiego $^{70}$ i poruszona przez profesora teologii Jana Isnera w jego testamencie (22 III $1410)^{71}$, leżała także na sercu Piotrowi Wyszowi. Dał on temu wyraz, gdy 15 maja 1401 roku wcielal pięć prebend do studium generalnego w Krakowie ${ }^{72}$. Mimo utarczek i dolegliwości codziennego życia, ta idea, której miał służyć przede wszystkim wydział teologiczny, nie straciła na znaczeniu.

Wielkie wyrzeczenia i niezwykła ofiarność wielu pierwszych wykładowców i profesorów sprawiły, że jagiellońska fundacja wydziału teologii i odnowa całego Uniwersytetu Krakowskiego po trudnym okresie „dzieciństwa” rozwinęła się wspaniale w XV wieku. Przy różnych okazjach dziękowali oni za to obojgu królewskim fundatorom. Archịdiakon krakowski Andrzej z Kokorzyna, uchodzący już w XV wieku za największego polskiego filozofa tego okresu, powiedział pięknie w roku 1413, że król Polski Władysław wzniósł krakowskie studium generale ${ }^{73}$, ale filarami, na których ono się oparło, stały się niezliczone dobra królowej Jadwigi, przeznaczone na jego uposażenie.

praefatus pro bono statu Universitatis et in eadem studentium praedictorum, similiter tunc expressa" (KodUJ 1 s. 90).

67 „Nec non huiusmodi privilegiorum, immunitatum et libertatum, ut eo firmus observarentur, Episcopum Cracoviensem, qui esset pro tempore, constituit conservatorem dans ei (potestatem) tuendi easdem libertates, illas quoque in rebelles et malefactores exequendi, et poenas, quas tam vigore earundem ordinationum Regis praefati, quam etiam secundum leges et Canones aut Statuta municipalia locorum mererentur, ipsorum transgressores et eorum exigentibus maleficiis atque contumacia ratione praevia declarandi, nec non etiam cum ipso Rectore Universitatis eiusdem salarium pro praefatis Magistris et Doctoribus collegiatis, et alia commoda in eodem Collegio iuxta exigentiam status et meriti cuiuslibet eorundem Magistrorum et Doctorum pariter distribuendi" (tamże).

68 Zob. M. Gę ba rowicz, jw., s. 48 (przypis 55).

${ }^{69}$ Zob. niżej aneks 2.

${ }^{70}$ Zob. wyżej przypis 53.

71 Zob. wyżej przypis 58 i 59.

72 „Ad fidei catholicae propagationem, eiusdem Studii Cracoviensis dilatationem et uberius incrementum, neophitarum que praedictarum gentium Lytwanicae, Ruthenicae et Watachicae clariorem salutis illuminationem uberem" (KodUJ 1 s. 38).

73 "Gratia eius in vacua non sit per intercesionem illius quae nec primam similem visa est nec habere Deum refero gratiarum actiones et demum gloriosissimo martyri ac pontifici paterno sancto Stanislao, totique tam triumphanti quam militanti ecclesiae, serenissimo principi et domino Wladislao regi Poloniae qui erexit hoc studium nobis" (zob. M. Markow s ki, Wyktad wstępny Andrzeja z Kokorzyna, „Materiały i Studia Zakładu Historii Filozofii Starożytnej i Sredniowiecznej” 2: 1962 s. 49). 


\section{ANEKSY}

\section{Zatwierdzenie fundacji Kollegium litewskiego w Pradze przez króla Wtady- stawa IV, ogtoszone 20 lipca 1397 roku.}

Druk: Codex diplomaticus almae Carolo-Ferdinandeae Universitatis Pragensis originem, incrementa, privilegia, jura, beneficia aliaque fata, tum prospera, tum adversa illustrans, [w:] Monumenta historica Universitatis Carolo-Ferdinandeae Pragensis, t. 2/1, Pragae 1834, s. 355 - 358.

Wenceslaus Dei gratia Romanorum rex semper augustus, et Boemiae rex. Notum facimus tenore praesentium universis. inter cetera, quae sollicitudinis nostrae cura cottidiana et diligenti meditatione revolvit, illud occurrit nostrae considerationi praecipuum, qualiter venerandus orthodoxae fidei nostrae cultus ampla occidui orbis extendatur in climata, populoque sedenti in tenebris et in umbra mortis lux adoptata resplendeat, ut qui eatenus errore miserabili ferebatur in devium, post periculosam negligentiam ad viam salutis redeat, et vias suas tam lamnosas tamque pestiferas finaliter derelinquat. Etenim conditor orbis, omnipotens Deus, sicut inter illa nascentis fidei cunabula, ac teneram ecclesiae lactantis infantiam populum suum sanctae praedicationis eloquiis erudiri constituit, sic et nunc vergente in senium saeculi corruptela, converso ad se delectatur in populo vaporantis fidei ardore succenso in tantum, ut si hunc religiosi itineris vias ac veritatis semitas perambulare, et in eis manere conspexerit, non solum ipsum de antiqui hostis dominio eripere, verum etiam regni coelestis eidem dignetur januam aperire.

Sane pro parte serenissimae principis d(omi)nae Hedvigis, reginae Poloniae etc., sororis nostrae carissimae oblata nuper majestati nostrae petitio continebat, quod cum ipsa ad propagandam in terris et dominiis suis, ac etiam locis circumvicinis sacrosanctam fidem catholicam certas personas a partibus Lytwaniae vel alibi oriundas eligere, ipsasque ad studium civitatis nostrae Pragensis decreverit destinare sub eo proposito, ut ibidem sacra facultate theologica cognita, et, quantum ipsis ab alto concessum fuerit, realiter apprehensa veritatis doctrinam in gentes illarum partium, quae hactenus nec dominum norunt, nec ejus nomen magnificum invocarunt, debeant fideliter derivare. Ad usus

74 „Recommendo vobis bonae memoriae reginam Hedvigem propagatricem verbi divini et speculum totius humilitatis ac incitamentum ad omnium bonorum morum actiones. Ipsa enim supergressa est universas principes et reginas zelo quem ad verbum Dei habuit, ad quod disseminandum a variis partibus praedicatores ad se vocavit ad quorum pedes prima et ultima ad audiendum verbum Dei humillima se collocavit, et fulcimenta ad erigendum hanc almam Universitatem incertis bonis mobilibus derelinquit quae postea ad effectum optatum clare deservierunt" (tamże, s. 50 $-51)$. 
quoque dictarum personarum studere debentium domum in eadem civitate nostra Pragensi, nec non decentas sexagenas census annui providerit comparandum, quatenus emptioni domus et census hujusmodi consensum nostrum adhibere, ipsam quoque domum et censum ad usus dictarum personarum appropriare, annectere et inviscerare gratiosus dignaremur.

Nos praefatae sororis nostrae precibus utpote rationabilibus atwue justis benignius inclinati, non per errorem aut improvide, sed animo deliberato, sano fidelium nostrorum accedente consilio, regia auctoritate Boemiae, et de certa nostra scientia ad honorem omnipotentis Dei, totiusque curiae coelestis, et signanter pro roboranda nostris temporibus sacra fide catholica, ad hoc, ut pracfata soror nostra, seu ipsius procuratores pro habitatione personarum hujusmodi studere debentium, domum in civitate nostra Pragensi, majori videlicet aut nova, comparare possint et valeant, consensum nostrum regium adhibuimus, et virtute praesentium gratiosius adhibemus, ipsamque domum cum area et circumferentiis suis ex nunc prout ex tunc, et ex tunc prout ex nunc ab omnibus et singulis angariis, perangariis, stewris, losungris, exactionibus, impositionibus, ac allis gravaminibus, quocumque nomine censeantur, exemimus, et libertavimus, eximimus, et tenore praesentium totaliter libertamus; et similiter censum ducentarum sexagenarum praecedentium per eandem sororem nostram, seu ipsius procuratores in regno nostro Boemiae in bonis tamen liberis, sed non feodalibus, simul aut successive comparandum ad usus personarum studere debentium, ut praefertur, ex nunc prout ex tunc, et ex tunc prout ex nunc appropriamus, annectimus et incorporamus per ipsas ex nunc in antea perpetuis temporibus juxta dispositionem et ordinationem supra dictae sororis nostrae, seu procuratorum ipsius habendum, tendendum et pacifice possidendum, litteras quoque per eandem sororem nostram, seu ipsius procuratores tam super domo, quam etiam censu supradicto datas vel dandas, et omnem ipsius seu eorum dispositionem, ratas habentes et gratas, ipsas regia auctoritate praedicta, et de certa nostra scientia approbamus, ratificamus, et praesentis scripti patrocinio gratiosius confirmamus; mandantes nihilominus universis et singulis baronibus, nobilibus, militibus, clientibus, burggravvis, officialibus civitatum, et oppidorum communitatibus, et signanter magistris civium, consulibus et scabinis majoris et novae civitatum Pragensium, qui nuns sunt, vel pro tempore fuerint, firmiter et districte, quatenus praefatam sororem nostram, seu ipsius procuratores in emptione domus et census, praefatasque personas studere debentes in possesione domus, aut perceptione hujusmodi nequaquam impediant, nec impediri per quempiam patiantur; quin potius circa hujusmodi protegant, manute neant fideliter, et defendant, prout gravem indignationis nostrae offensam voluerint arcius evitare. Praesentium sub regiae nostrae majestatis sigillo testimonio litterarum.

Datum Pragae, anno Domini millesimo trecentesimo nonagesimo septimo, 
die vicesima Julii, regnorum nostrorum anno Boemiae tricesimo quinto, Romanorum vero vicesimo secundo.

Ad relacionem Sigismundi subcamerarii Wlachnico de Weytenmule.

[A tergo]: R. Bartholom. de Nova civitate.

2. Dokument fundacyjny Kolegium litewskiego w Pradze, wystawiony przez królowę Jadwigę w Krakowie 10 listopada 1397 roku, w którym potwierdza kupno domu na użytek studentów litewskich, pragnacych poświęcić się nauce teologii, uposaża go 200 kopami groszy praskich $i$ wyznacza jego opiekunów.

Druk: tamże, s. $359-363$.

In nomine Domini, amen. Ad perpetuam rei memoriam. Cum spectabile opus, et actus laudabilis sit principium, universis et singulis sibi subditis suae januam elementiae aperire, sed longe magis illud est clarius, et laudis affert praemium dignioris, inter alios, quibus suae munificentiae dexteram porrigit, et maxime illis, qui christianae religionis instantia se divinae majestatis servitio, per quam reges regnant, et principes principantur, vita saeculari et arescentis saeculi vanitatibus postpositis, dedicarunt; sic enim equilibrate satisfacit debito rationis, sic fideles in fidei perseveratia consolidat et confirmat, sic divinis obediens cultibus, regis superni gratiam promeretur.

Proinde Nos Hedvigis, Dei gratia regina Poloniae, et heres Hungariae regnorum etc. significamus universis, wuibus expedit, praesentium notitiam habituris, quod considerantes et diligenter dirigentes aciem nostrae mentis, quomodo a tempore, quo Deo auspice sulmina concendimus regni nostri, in terris nostris Lithuaniae, et aliis convicinantibus eisdem, populus, qui in gehennalis mortis caligine ambulabat, de coecitate perfidiae ad lucem, Deum verum dudum incepit consurgere, atque sacri baptismatis fonte in maxima parte jam renatus, sacrosancte Romanae ac universalis ecclesiae unitatem firmiter teneat, et eidem faciat obedientiam reverentem, jamque nonnulli de Lithuanorum et aliorum inibi filiis sancti Spiritus rore perfusi ad scolasticumstudium catholicum, tamquam cervus ad fontes aquarum, sitentes confluunt, et disciplinam docentium eos mansuetissime amplectendo, jam quasi modo geniti infantes lac, et tamquam felix Chananaca micas verbi Dei, quae cadunt de mensa nobilis et opulentissimae theologiae, et in orbe semen ejus seminantium concupiscunt; unde nos volentes, quantum nobis ab alto conceditur, ut in praedictis neophitis non solum scientiarum et virtutum claritas, quae olim tenebrescebat erroribus, fidei catholicae splendoribus serenius modo jam diescat; verum etiam sole justitiae Christo Jesu in ipsos, velut in clypeos aureos refulgente, montes populi Lithuani et aliorum in operibus catholicis inextinguibiliter resplendeant 
ab eisdem, vineaque Domini Sabaoth per eos ibi indeficienter plentetur, ac urticae perfidiae in atrio Domini pungentes radicitus extirpentur, sicque ipsis animas Christo lucrifacientibus operationes pias, quas ad haec eis de bonis a Deo nobis creditis cooperamur, et seminamus in hac telure mortali, colligere in aeterna beatitudine valeamus. Horum contemplatione invigilavimus sollicite, et quomodo affectum manciparemus effectui, plurimas noctes transivimus insomnes et iactantes in Domino cogitatum, decrevimus unam domum, et cum hoc ducentas sexgenas grossorum ad usus dictorum Lithuanorum, et aliorum in sacra pagina studere volentium in civitate Pragensi vel citra comparandas, dummodo serenissimi principis domini Wenceslai, eadem gratia Romanorum regis, et Boemiae regis semper augusti, fratris nostri carissimi, ad id voluntas accederet et consensus. Et quoniam ipse dominus rex, frater noster carissimus, nobis justa desiderantibus gratiam in eo faciens, ad hoc assensum suum praebuit et consensum per literas suas sigillo suo communitas, quarum tenor de verbo ad verbum sequitur, et est talis: 'Wenceslaus Dei gratia Romanorum rex semper augustus, et Boemiae rex. Notum facimus tenore praesentium universis; inter cetera, quae sollicitudinis nostrae cura cottidiana'. - Nos igitur Hedvigis, regina praedicta, de hujusmodi gratia per ipsum dominum regem, fratrem nostrum carrissimum, nobis facta contentae literas ejus praescriptas per omnia ratas gratas habentes, perpetuo atque firmas idem domino regi multas pro eo referimus gratiarum actiones, cupientesque gratiam hujusmodi nobis factam deducere ad effectum, ex eo, quia de talibus inibi Pragae disponere praesentialiter non valemus, constituimus, ponimus, facimus, et modo, forma, quibus melius possumus, de certa nostra scientia ordinamus nostros veros legitimos, et indubitos procuratores, actores, factores, negotiorum gestores et nuncios speciales ac etiam generales, ita, quod specialitati generalitas non deroget, nec e contra, honorabilem et religosum ac honestos viros, videlicet magistrum Joannem, dictum Sczekna, fratrem ordinis Cisterciensis, sacrae theologiae baccalarium, plebanum de Przemancow, curiae nostrae capellanum familiarem, devotum, dilectum, praesentem, et in se onus procurationis [fere deletum] sponte suscipientem, Crucem institorem, et Nyepronem, cives majoris civitatis Pragensis, absentes tamquam praesentes, omnes, et quemlibet eorum in solidum, ita, quod non sit melior conditio occupantis, sed quod unus eorum inceperit, alter prosequi, mediare valeat et finire; dantes et concedentes virtute praesentium eisdem procuratoribus nostris, et eorum cuilibet plenum mandatum et omnimodam potestatem, domum et censum annuum praedictos emendi, comparandi, exsolvendi, ordinandi, disponendi, procurandi, personas studere debentes recipiendi, admittendi, destituendi, et si necesse fuerit, iterum resumendi, domum hujusmodi regendi, tuendi, reparandi, de ea disponendi, censum praedictum levandi, quietandi, de eo disponendi, convertendi, agendi, defendendi, libellum seu libellos aut quaecumque alia jura, argumenta seu documenta offerendi, offerri videndi, copiam seu copias productorum quorumcumque, et in- 
strumenta, ac quavis literas necessarias potendi, recipiendi, testes, probationes et articulos inducendi, induci videndi, a quocumque gravamine appellandi, appellationem prosequendi, unum vel plures procuratorem seu procuratores loco sui substituendi, recovandi, et in se onus procurationis resumendi, quando et quotiens eis, vel alteri eorum videbitur opportunum, omniaque alia et singula in facto (?) domus et census praedictorum faciendi, procurandi et exercendi, quae veri et legitimi procuratores in talibus et circa talia facere debent et consueverunt, et quae nosmet faceremus, si praemissis personaliter interessemus, promittentes tenore praesentium omnia et singula rata, grata atque firma perpetuo tenere, et irrevocabiliter observare, quaecumque per memoratos procuratores nostros, aut eorum alterum, vel substitutos ab eis acta, facta, procurata, seu ordinata fuerint in praemissis et quolibet praemissorum. Harum, quibus sigillum nostrum appensum est, testimonio literarum.

Datum Cracoviae die decima mensis Novembris anno Domini millesimo trecentesimo nonagessimo septimo. Per manus honorabilis Alberti Jastrzambecz, Gnesnensis et Cracoviensis ecclesiarum scolastici, cancellarii aulae nostrae fidelis dilecti.

\section{Poczqtek statutu dla praskiego kolegium królowej Jadwigi, które rozpoczęto} swą dziatalność 29 kwietnia 1411. Statut nie wspomina nic o Litwinach.

Oryginal: Archiwum Uniwersytetu Karola w Pradze, I 61(61).

Druk: C. Zaw odzińs k a, Kolegium królowej Jadwigi przy Uniwersytecie Karola w Pradze i jego pierwszy statut, ,Zeszyty Naukowe Uniwersytetu Jagiellońskiego. Prace Historyczne” 56 : 1962 z. 9 s. $31-36$ (poniższy przedruk dotyczy s. $31-32$ ).

In nomine Domini. Amen. Anno nativitatis eiusdem millesimo quadringentesimo undecimo, indictione quarta, di penultima mensis aprilis hora vesperorum, pontificatus sanctissimi in Christo patris et domini nostri domini Johannis divina providencia pape vicesimi tercii anno primo, in maiori civitate Pragensi in palacio superiori domus habitacionis providi viri domini Crucis institoris et civis dicte civitatis contiqua pretorio civitatis prefate, in mei notarii publici infrascripti et testium presencia subscriptorum, ad hoc specialiter vocatorum, constitutus personaliter prefatus dominus Crux civis procurator et ordinator legittimus ac executor et fidei commissarius illustris principis quondam Hedwigis regine Poloniae, ut dicebat, quandam ordinacionem et disposicionem de et super certis censibus annuis ac domo sita in loco qui dicitur Jerusalem in dicta civitate Pragensi sita per eum pro magistro et studentibus in eadem domo morantibus presentibus et futuris per eum factan et in scriptis redactam facit desposuit, condidit et oridnavit ipsamque de verbo ad verbum legi facit coram magistro et studentibus dicte domus in Jerusalem site, cuius tenor de verbo ad verbum sequitur et est talis.

In nomine Domini. Amen. Ego Crux institor, civis maioris civitatis Pragen- 
sis, procurator et ordinator legittimus et excecutor ac fidei commissarius serenissime principis et recolende memorie quondam domine Hedwigis regine Polonie ad negocia infrascripta specialiter deputatus, quemadmodum in litteris predicte domine Hedwigis regine, cum consensu serenissimi principis ac domini domini Wenceslai Romanorum et Boemie regis, sigillo sue magestatis sigillatis debite continetur, magistro Johanne Sczekna et Nyeprone cive Pragensi michi huiusmodi ordinationem commitentibus et ius suum resignantibus, prout testibus fidedignis bene constat et in tabulis Regni Boemie eciam est expressum, volens commissum et creditum michi onus diligenter et fideliter exequi et futuris periculis evitandis quantum in me est providere, ne in futurum lites de hoc negocio commitantur, disposui et ordinavi ac dispono et ordino cum consilio magistrorum et aliorum, quos de hoc specialiter requisivi, iuxta modum et formam quibus melius proferat tunc videri, de domo et studentibus per reginam prefatam ac per me tanquam eius commissarium et procuratorem finaliter ordinatum. Que domus nunc est in maiori civiate Pragensi iuxta cepellam sancte Marie Magdalene, dictam wulgariter in Jerusalem, que certo modo ab abbate et conventu monasterii Auleregie ordinis Cisterciensis est conducta, prout in litteris dicti abbatis et conventus lacius est expressum, sed postea per me vel alium meum substitutum patronum et predicatorem alibi ordinabitur, sicut eis videbitur expedire.

\section{DIE JAGELLONEN-STIFTUNG DER THEOLOGISCHEN FAKULTÄT IN KRAKAU}

\section{Zusammenfassung}

Während der König Kasimir der Große das Studium Generale in Krakau am 12. Mai 1364 stiftete, hatte er noch keine Genehmigung der Gründung der Theologischen Fakultät vom Papst erhalten. Die Bitte um eine solche Genehmigung hatten die Königin Hedvig und der König Ladislaus Jagiełło erneut zur Zeit des Pontifikats von Urban dem VI. (gestorben vor dem 15. 8. 1389), im 1392 und 1396 vorgelegt. Am 11. 1. 1397 kam die Genehmigung vom Papst Bonifaz dem IX., die zuließ, daß die Theologische Faktutät in dem schon bestehenden und im begrenzten Umfang wirkenden Studium Generale gestiftet werden konnte. Als eine besondere Auszeichnung seitens des Papstes ist die Verleihung der neugegründeten Fakultät der gleichen Rechte wie der alten Theologischen Fakultät in Paris anzusechen. Die nicht genug klar bestimmte Frage des Kanzleramtes wurde zur Ursache des Streites um Besetzen dieses Postens zwischen dem König Jagielło mit seinen Beratern einerseits und dem Krakauer Bischof Peter Wysz anderseits. Im Sommer 1397, ohne die Perspektiven einer baltigen Beendigung des Streites zu sehen, hatte die Königin Hedvig, beschlossen ein spezielles Kolleg für Litauern zu gründen, damit sie sich in Teheologie weiterbilden konnten. Sie hatte jedoch aufgegeben, es weiterhin zu finanzieren, wenn die Hoffnung auf die Stiftung der Theologischen Fakultät in Krakau wieder entstand. Die Königin Hedvig konnte jedoch nicht mehr die offizielle feierliche Eröffnung des Studium Generale mit der Theologischen Fakultät an der Spitze erleben. Das von ihr hinterlassene Vermögen ermöglichte und sogar beschleunigte die Unternehmung, eine der größeren in der Geschichte der polnischen Wissenschaft. 